Chapter 3

\title{
CROP PRODUCTIVITY AND POTENTIAL
}

\author{
Guush Berhane, Bart Minten, Fantu Bachewe, \\ and Bethelhem Koru
}

\section{Introduction}

Ethiopia has registered an average annual GDP growth rate of 10.3 percent over the 2005/2006-2015/2016 period (Bezawagaw et al. 2018), a remarkable achievement for a country with little dependence on natural resources such as oil or minerals. Critical to these changes were strong political commitments that put agriculture at the center of Ethiopia's development agenda since the 1990s (Berhane, Bachewe, and Minten 2018). Spearheaded by public investments, GDP growth has been largely driven by growth in the agricultural sector (Bachewe et al. 2018; Hill and Tsehaye 2018). For more than two decades, Ethiopia's growth strategy has remained agriculture-focused, as shown by a budget exceeding the CAADP agriculture investment target of 10 percent of the national budget (Mellor 2014; AGRA 2018). Within agriculture, crop productivity has received substantial attention as significant investments were made in its extensive extension system and in ensuring access to modern inputs (Berhane et al. 2018). Parallel investments in roads, safety nets, education, and health have also contributed to subsequent recovery and turnaround of the sector.

Largely driven by public investments and favorable economic conditions, Ethiopia's total value of smallholder crop output more than doubled-from 14 million metric tons in 2004/2005 to 32 million metric tons in 2015/2016. Average crop output grew between 8 percent to 13 percent a year and cereals accounted for a lion's share of the total crop output growth. In the same period, land under cultivation has expanded by about 27 percent, 90 percent of which was used for cereals (but later declined and leveled off), and average cereal yield has increased by about 5 percent a year. Output growth was attributed to land expansion as well as yield growth (Bachewe et al. 2018). However, despite high growth rates, Ethiopia's yield levels remain rather low and they are showing signs of slowing down recently. A key question is therefore whether Ethiopia can sustain productivity increases to achieve further 
agricultural transformation in the face of declining additional cultivable land and the recent slowing down of yields.

This chapter tries to answer this question by assessing the patterns, sources, and prospects of crop productivity in Ethiopia. We discuss the sources of crop output growth and assess the role of land, labor, technological inputs (for example, fertilizer, improved seeds, extension, and so on) as well as total factor productivity (TFP), a key measure of sustained long-term growth. We provide an overview of key policy achievements, focusing on fertilizers, improved seeds, credit, the extension system, irrigation, and mechanization. We outline existing structural bottlenecks for future growth. We contextualize the discussion by comparing Ethiopia's recent achievements with selected recent experiences of African (Burundi, Kenya, Malawi, Niger, Nigeria, Rwanda, Sudan, Tanzania, and Uganda) and Asian (China, India, Indonesia, Malaysia, and Thailand) countries-the latter when they were at about the same level of development as Ethiopia is now.

We find that expansion in cultivated land and labor have, respectively, accounted for about 13 percent and 30 percent of Ethiopia's observed crop output growth in the past decade. Expansion in use of chemical fertilizers, improved seeds, and extension were also important contributors. Moreover, TFP growth has contributed to about 18 percent of output growth in the same decade, suggesting efficiency gains of investments in the production process. However, TFP growth has declined in most recent years (from 38 percent in the beginning of the period to 16 percent at the end of the period), contributing to the recent slowdown in yield growth. The decline has continued despite continued investments in TFP increasing nonconventional inputs such as extension and chemical fertilizers. The contributions of land and labor inputs have also remained roughly the same, suggesting additional gains in and keeping up with sustained productivity is likely to be increasingly difficult. We discuss the most important bottlenecks behind this slowdown and highlight potential ways going forward.

\section{An Assessment of Crop Production Patterns}

Ethiopia's investment in agriculture since 2004/2005 has mainly focused on crop production. As a result, the lion's share of agriculture's contribution to GDP growth comes from growth in crop production (Bachewe et al. 2018). In the decade between 2004/2005 and 2013/2014, Ethiopia's agriculture sector on average grew by 7.6 percent annually, which accounted for 3.6 percent of the 10.7 percent real GDP growth in this period. The agricultural sector 
has on average contributed 47 percent to real GDP, 32 percent of which was accounted for by the crop subsector. ${ }^{1}$

This section focuses on this important subsector in Ethiopian agriculture (the livestock subsector is dealt with in a separate chapter). We begin with assessing trends in the real value of crop output (valued using the monthly producer prices of Ethiopia's Central Statistical Agency [CSA] and adjusted for inflation by regional price indexes) and report on growth rates in production, area cultivated, and yield. We discuss trends for major food grains in the main production season (called meher), while also highlighting the types of crops grown in Ethiopia. The data used are from CSA's annual crop output reports (Ethiopia, CSA Volume 1,2005-2016) computed based on annual agricultural sample surveys. ${ }^{2}$

We update the evidence provided in Bachewe et al. (2018) to the most recent years for which data are available and discuss the potential and constraints for further growth in this sector in the years ahead. To help frame the discussion on further potential, we put the Ethiopian experience into an international context.

\section{Trends in Crop Output, Area Cultivated, and Yield}

Ethiopia's total value of crop output grew from 14 million metric tons in 2004/2005 to 36 million metric tons in 2017/2018 - that is, an average growth rate of 9 percent per year (Table 3.1). Average crop output grew between 8 percent to 10 percent a year in the early years of the decade but had slightly fallen to 5 percent in 2011/2012 and then rose to about 10 percent to 13 percent annually in the last three years of the decade. Cereals accounted for about 72 percent of the total crop output and grew by 8 percent a year. Maize is among the top drivers of this growth in cereals (Abate et al. 2015). Fruit crops also grew rapidly - that is, by an average of 12 percent a yearalthough growth was sporadic over the 11 years and fruit crops are only grown by a few holders in relatively small pockets of the country. Pulses and oilseeds - some of them used for exports—have also performed well, particularly toward the end of the decade, suggesting the increasingly important contributions of commercial crops. However, compared to cereals, their share

1 Agriculture remains a major employer in the Ethiopian economy, accounting for 80 percent of all workers in 2005 and 77 percent in 2013 (Bachewe et al. 2018).

2 The analysis in this chapter, unless indicated otherwise, uses data from the annual smallholder agricultural production survey collected by Ethiopia's Central Statistical Agency (CSA). Recent investments by large commercial farmers mainly in the lowlands has limited spillovers to smallholders (Ali, Deininger, and Harris 2019) and is separately treated in Chapter 7. 


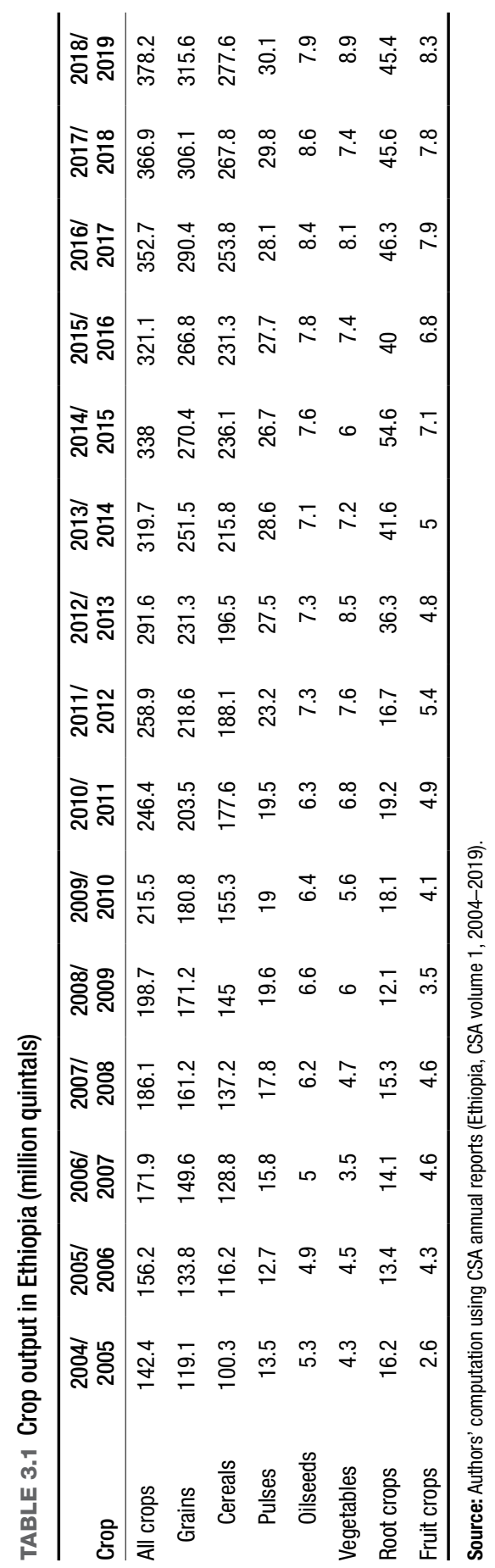


in total grain output remains low. Roots crops, a common staple in southern parts of Ethiopia, have become a dynamic subsector in recent years, doubling in production from 1.8 million metric tons in 2009/2010 to 3.6 million metric tons in 2012/2013, and then increasing to 4.2 million metric tons in $2013 / 2014$. Vegetables have also achieved notable growth-with a growth rate of 6 percent a year-albeit at fluctuating rates over the decade considered. The latter could be due to changes in access to irrigation, which varies across years depending on availability of moisture as well as the increasing incidences of diseases.

Growth in output has been accompanied by growth in crop yields (defined as the ratio of value of output to area cultivated). Table 3.2 reports crop yields for the period 2004/2005 to 2018/2019 (see Table 3.3 for area cultivated). In general, yield has substantially increased (about 6 percent annually) for all crops over the 12 years considered, albeit from a low base. Among grains, cereals have seen the highest yield growth rate-almost doubling from 11.8 quintals per hectare in $2004 / 2005$ to 26.8 quintals per hectare in 2018/2019-followed by pulses and oilseeds. ${ }^{3}$ Among the nongrains, oilseeds register the lowest yield levels while root crops saw the highest yield levelsfor example, 195.9 quintals per hectare in 2018/2019_followed by fruits at 60 quintals per hectare to 70 quintals per hectare. However, these latter crops constitute only a tiny share of the total cultivated land in the country, and the area covered by these crops has stagnated over the period considered.

Given the importance of cereals in Ethiopia's crop agriculture, we present statistics on the dynamics of individual crops separately. Bachewe et al. (2018) show that during the 2004/2005-2014/2015 period, cereals, composed of five important crops-teff, maize, wheat, sorghum, and barley-accounted for 63 percent of real value of crop output (and contributed the lion's share of the smallholder agriculture economy in Ethiopia) and that the extent of crop diversification remained stable over the decade considered. The four major cereal crops have seen an average annual yield growth rate of 18 quintals per hectare for 15 consecutive years (Figure 3.1). However, yield growth varies by crop. Maize stands out with the highest average annual yield growth (25.5 quintals per hectare), followed by wheat (18.9 quintals per hectare), barley (15 quintals per hectare), and teff (12.4 quintals per hectare). Clearly maize has seen an expanding share of production within staples in the same period and is now the second-most widely cultivated crop in Ethiopia (Abate et al. 2015).

3 A quintal is equal to 100 kilograms. 


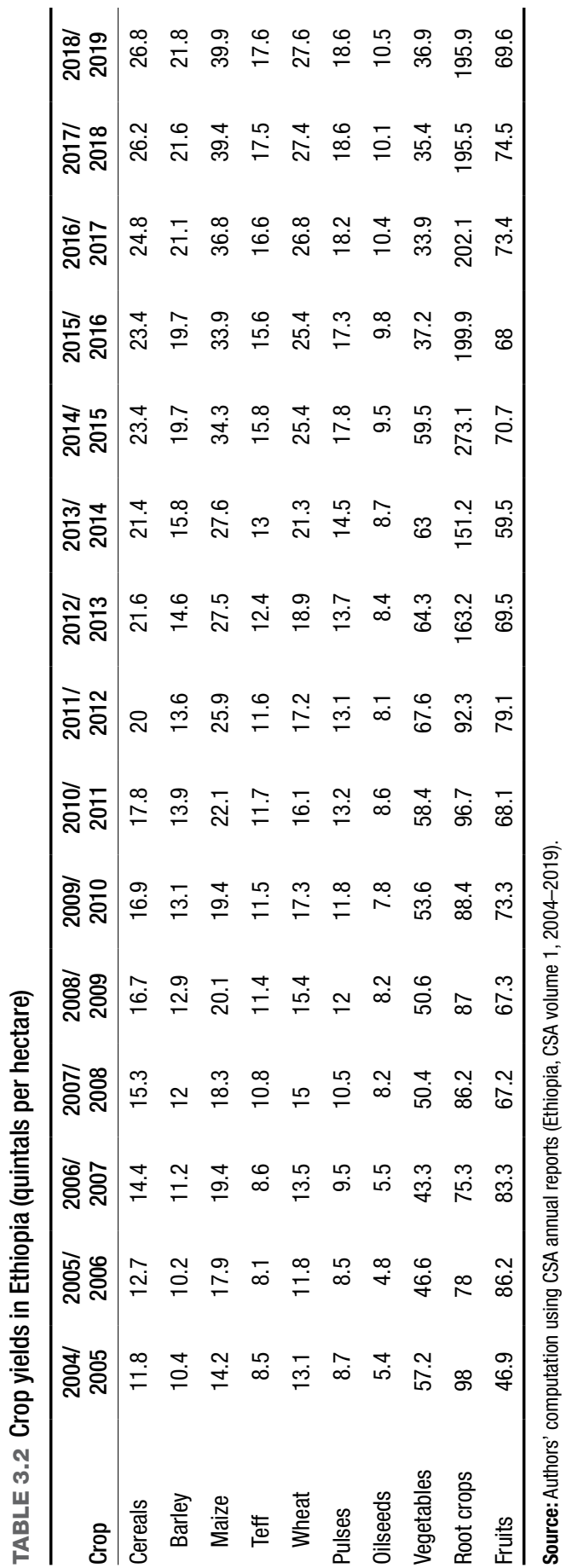


FIGURE 3.1 Yield growth of maize, wheat, barley, and teff, 2004/2005-2017/2018

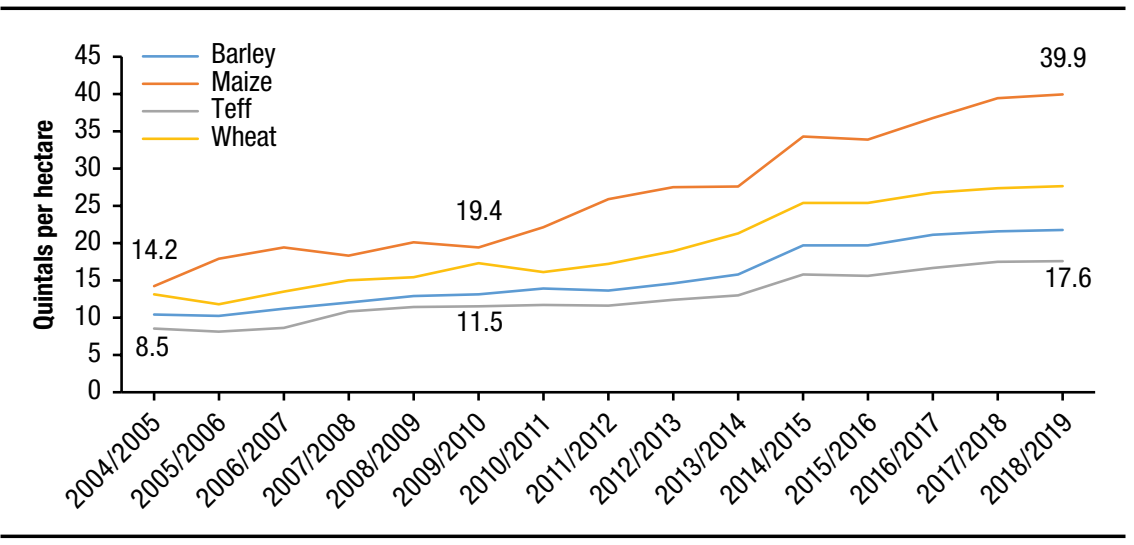

Source: Authors' computation using Ethiopia, CSA annual reports (Ethiopia, CSA 2005-2018).

While the aggregate crop output has more than doubled over the decade under consideration, the number of holders also grew from 11 million in $2004 / 2005$ to 15.7 million in $2017 / 2018$. $^{4}$ An increase in the number of holders given limited available land resources means that additional output gains from expanding cultivable land has declined (Headey, Dereje, and Taffesse 2014). Table 3.3 reports trends in cultivated area covered by grains, vegetables, root crops, and fruits (see also Figure 3.2). There are three important points to note from Table 3.3. First, considering all crops, an additional 3.1 million hectares of land has been cultivated between 2004/2005 and 2018/2019, a 31 percent increase from land cultivated in 2004/2005. Second, about 90 percent of the cultivable land added is used for cereals, and land under cash crops except for pulses (which increased by about 30 percent) has only slightly increased, or the increase is insignificant given the low base (as in the case of vegetables). Third, expansion in cultivable land was rapid at the beginning of the decade-about 3.7 percent—but that expansion has quickly dwindled toward the end of the decade. While yield growth is positive but variable and with a declining trend (see trend line in Figure 3.2), expansion in cultivated acreage has eventually leveled off. The widening declining trend lines for yield and area expansion in Figure 3.2 further suggest that improvements in use of modern inputs and the extension system were not sufficiently compensating for

4 A holder is a person who exercises management control over the operation of his/her plots (Ethiopia, CSA 2014/2015). 


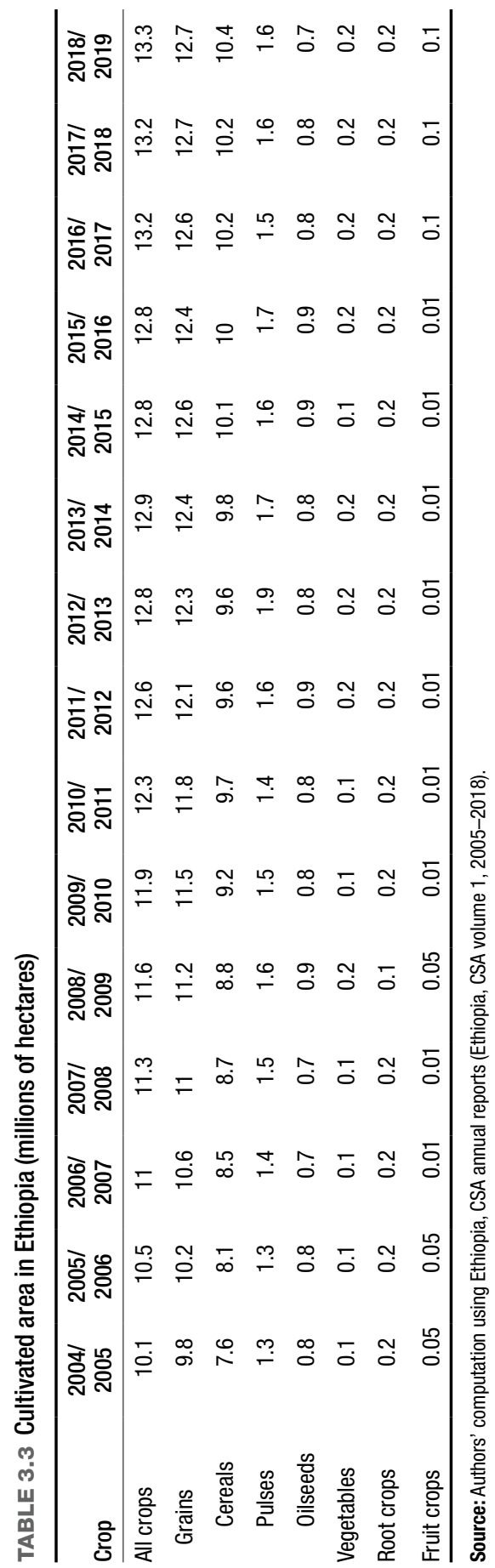


FIGURE 3.2 Growth in area cultivated and yield of grains (\%)

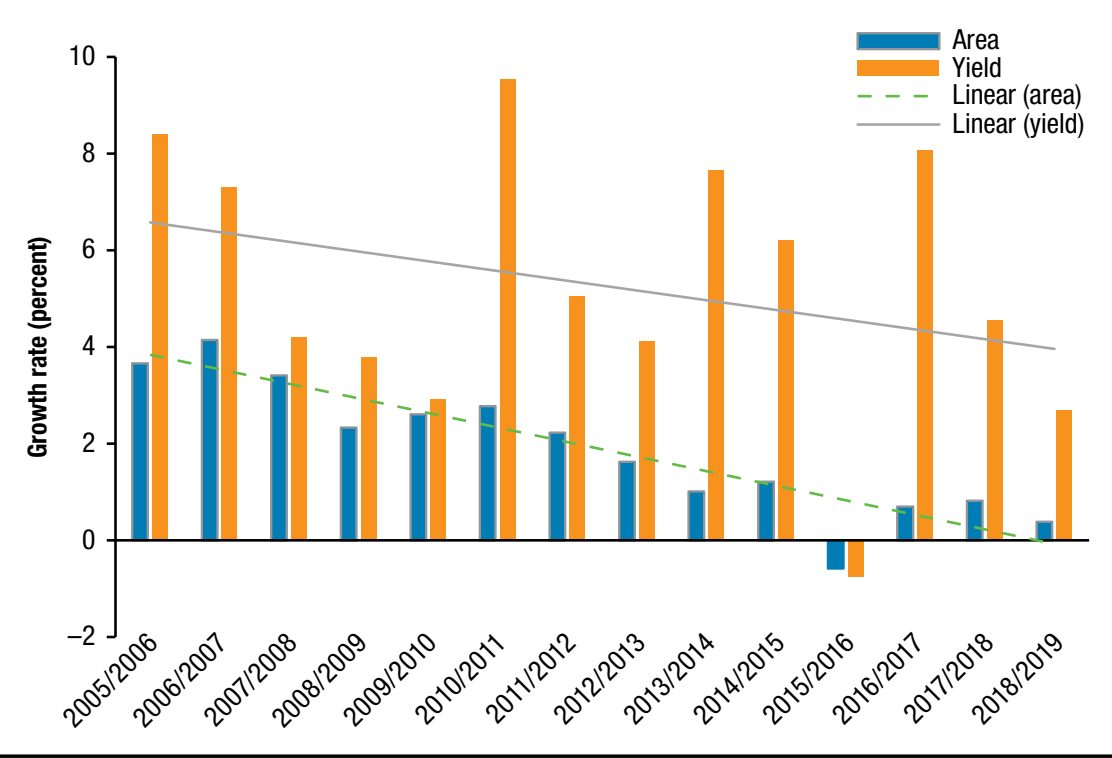

Source: Authors' computation using CSA annual reports (Ethiopia, CSA volume 1, 2004-2016).

declines in yield growth due to declines in area expansion (that is, given that the downward-sloping trend line for yield growth follows that of area expansion).

\section{Yield Growth in Ethiopia Compared to Other Countries}

For more than two decades, Ethiopia's overall agricultural growth surpassed the CAADP target of 6 percent growth (AGRA 2018). ${ }^{5}$ Cereal yield growth has been significant in the most recent 12 years of the two decades (that is, it grew by 4.9 percent a year), making Ethiopia among the best recent performers in Africa south of the Sahara (Mellor 2014). An important feature of Ethiopia's agriculture growth is yield growth, unlike that of many other Africa south of the Sahara countries whose growth heavily relied on expansion of area under cultivation and not yield (see Nin-Pratt 2016; Fuglie and Rada 2013; Bachewe et al. 2018; Mellor 2014).

To put this in perspective, we compare Ethiopia's yield growth in the period 2001-2012 to selected African countries for which comparable data from the other countries is available. Figure 3.3 reports the annual average

5 CAADP is the Africa-wide strategy developed by the African Union, where all heads of state of African countries have agreed to allocate at least 10 percent of their spending on agriculture (African Union 2010). 

growth rate, \%)

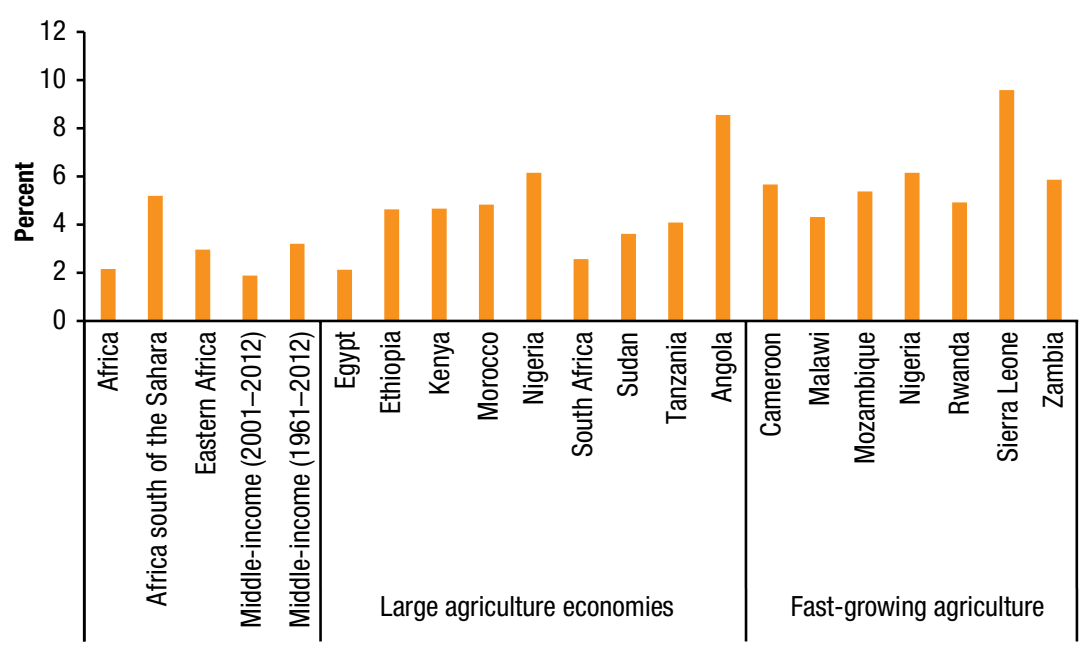

Source: Compiled from Benin and Nin-Pratt (2016).

Note: Large agriculture economies has at least 3 percent of Africa's total agricultural output; fast-growing agricultural economies surpass the CAADP agricultural growth rate target of 6 percent per year.

growth rate by group of African countries, mainly countries with middleincome status, and those that are deemed fast-growing as well as those with a large agricultural population share. With an average annual growth rate of 4.6 percent (only for the years for which we have data for other countries), Ethiopia clearly stands below the SSA average but surpasses the middle-income average of 3.2 percent per year for the period 2001-2012. It also performed well compared with many of the large agriculture as well as resource-rich and fast-growing agriculture economies except Angola, Nigeria, and Sierra Leone (which Ethiopia outperformed in most recent years). It is to be noted that these data are a bit outdated for Ethiopia, and its growth rate has gone up significantly since the years considered.

However, despite these recent high growth rates, yield levels are still rather low compared with what has been observed in many other contexts, particularly for crops in which Ethiopia has significant potential. Maize and wheat are among crops with high potential in Ethiopia given the promising fertilizerimproved seed responses observed for both crops in recent years and availability of relatively larger land suitable for both crops in the wheat and maize growing areas of the country (Abate et al. 2015; Mellor 2014). A cursory look at yield levels of these two important crops in Ethiopia against other countries 
FIGURE 3.4 Maize and wheat yield levels and growth rates for selected countries, 2004-2013

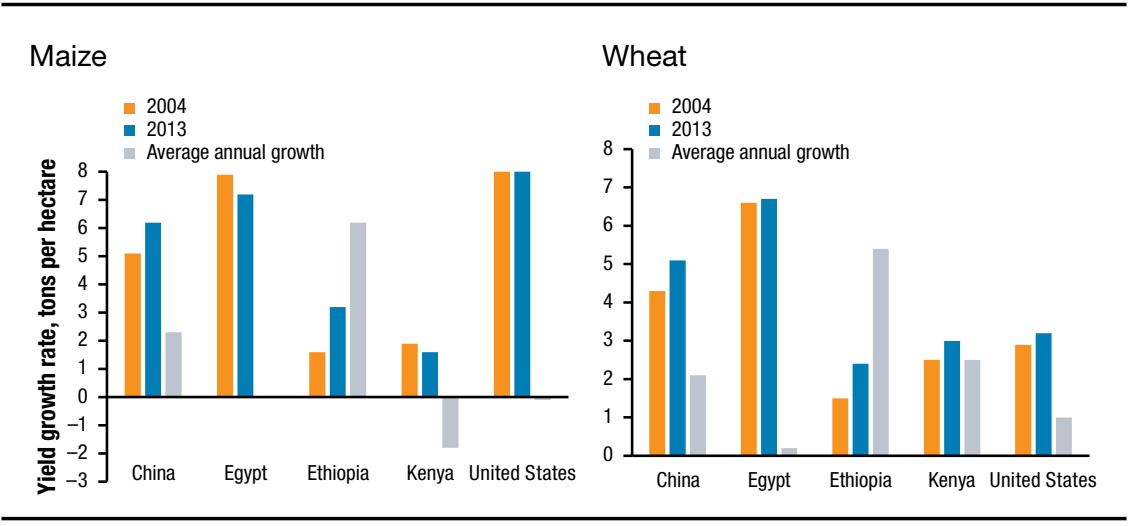

Source: Adapted from Bachewe et al. (2018).

can help shed light on this issue. Figure 3.4 shows yield levels and yield growth rates for maize and wheat for selected countries for the period 2004-2013. In 2004 maize yields in Ethiopia were respectively 25 percent and 20 percent lower than that of Egypt and the United Sates. This gap had declined by 2013 when Ethiopia's maize yield levels increased to 44 percent and 33 percent of that of Egypt and the United States, respectively. Clearly, although Ethiopia's maize and wheat yield growth rates have exceeded any of the countries presented in this discussion, including China (which has registered remarkable growth rates in both crops), Ethiopia's yield levels still remain low, suggesting a substantial yield gap that Ethiopia can catch up with.

\section{Trends in Productivity and Implications for Agricultural Transformation}

Sustained increase in agricultural productivity is the cornerstone for a successful agricultural transformation (Hazell 2009; Tomich, Kilby, and Johnson 1995). In agrarian economies like Ethiopia, decades of continued investments and government strategic leadership are needed for sustained productivity increases to achieve successful transformation (Hazell 2013). The descriptive evidence presented earlier suggests that Ethiopia's crop agriculture is on the move in the past decade. A fundamental question is what the key sources are of the recent output growth and whether such growth trends can be sustained into the future to achieve agricultural transformation in Ethiopia.

A key challenge in the agricultural transformation of Africa south of the Sahara is that growth has relied on expansion of the area under cultivation 
and not yield (Jayne, Chamberlin, and Benfica 2018; Nin-Pratt 2016; Fuglie and Rada 2013). In contrast, the yield (partial productivity) evidence presented so far shows Ethiopia's agricultural growth is associated with both area expansion and yield growth. However, comparisons with selected countries indicate that Ethiopia's yield growth occurs from a rather low base and as such yield levels lag far behind those required to achieve agricultural transformation as observed in Asia or elsewhere. Thus questions remain regarding the extent to which the recent takeoff can be sustained and whether Ethiopia is on the right track to transform its agricultural sector as envisioned by Ethiopia's Growth and Transformation Plans.

\section{TOTAL FACTOR PRODUCTIVITY}

To get better insights into these questions, we look at how Ethiopia's cropagriculture has fared in terms of total factor productivity (TFP), a more comprehensive measure of overall performance than, for example, yield growth. TFP is a favored measure of long-term productivity growth, as sustained increase in TFP is considered the core driver of sustainable agricultural transformation (Laborde et al. 2018). TFP is estimated residually as the rate of change in output not explained by the rate of change in conventional input use such as labor, land, and capital and TFP growth suggests that the same or fewer inputs can produce more outputs through more efficient ways of production, including through adoption of new technologies or shifts to better production methods (Sheng, Ball, and Nossal 2015). In short, "changes in TFP can be interpreted as a measure of the collective contributions of nonconventional inputs in agriculture, such as improvements in input quality, introduction of better ways of doing things, leading to technical change and economies of scale" (Fuglie 2004: 1; Ruttan 2002). TFP is often further decomposed into finer measures of technical change-referring to the movement of the technological frontier; efficiency change - referring to movement of individual farmers toward or away from the technological frontier; and scale-efficiency change-referring to movement of farmers above the technological frontier to capture economies of scale (Benin and Nin-Pratt 2016). We come back to these further refinements later in the chapter, and we focus on the decomposition of productivity into changes in TFP and other factors involved.

We use 12 years of CSA data on crop output, land, labor, fertilizers, improved seeds, irrigation, extension services, pesticides, and other factors. Bachewe et al. (2018) used a modified growth accounting model (Solow 1957) to decompose growth in real value of crop output into changes in input use, changes in TFP, and other exogenous factors that affect output growth. This 
study follows the same method and extends the analysis using two additional data points that have become available after that study. However, the following important caveats are in order when interpreting TFP results using this method. First, it is assumed that markets are competitive, and production is represented by an aggregate crop production function that can be expressed as a relationship between inputs and outputs where output levels increase with increases in these inputs. Second, due to lack of data, not all factors that can affect this production relationship are included in the analyses. These include, farmers' use of organic fertilizers, mechanization, and improved land and water management practices, as well as other exogenous factors, such as weather changes. Insofar as these factors are not included in the analyses, changes in TFP obtained from the analyses also include the effects of those factors (Sumner 2014).

We provide results of the growth accounting analyses (described above) in Figure 3.5. It presents the average contributions of inputs considered and TFP to crop output growth over the period 2004/2005-2015/2016. On average, change in labor, land, fertilizer, improved seeds, and access to extension has, respectively, accounted for 30 percent, 13 percent, 11 percent, 12 percent, and 7 percent of real output growth over the 11 years considered.

All other factors - namely irrigation, pesticides, and rural roads-had relatively smaller contributions, which is expected given the limited roles these still have in Ethiopian agriculture. Note, however, that in this method roads measure direct effects only but they indirectly affect modern input use, which were important drivers of growth. The remaining 18 percent growth in real output is accounted for by a change in TFP. These results are consistent with those reported in Bachewe et al. (2018), except that the TFP contributions have declined from 22 percent-in 2004/2005-2013/2014 to 18 percent in 2004/2005-2015/2016. ${ }^{6}$ As depicted in Figure 3.6, TFP growth has continued to decline substantially, slowing output growth from 15 percent a year in 2004/2005 to 7.2 percent in 2014/2015 and 3.4 percent in 2015/2016. When further disaggregated by a period of three to four years (see Figure 3.7), it is clear that average TFP contribution to output growth has decreased significantly from 38 percent in 2004/2005-2008/2009 to 16 percent in the most recent years of 2013/2014-2015/2016. It is important to note that TFP growth has continued to decline despite the fact that traditionally

6 Details of the contributions of each factor are presented in Table 3A.1 and Table 3A.2.

7 Figure 3.7 shows relative contributions of inputs and TFP to output growth disaggregated by growth episodes of three to four years in the decade. 
FIGURE 3.5 Average contributions of factors and total factor productivity to crop output growth, 2004/2005-2015/2016

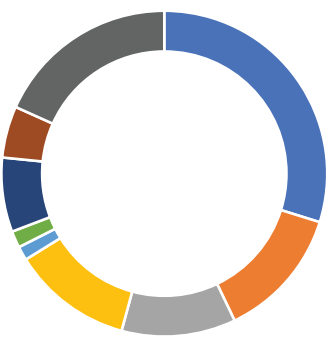

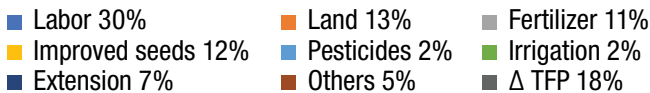

Source: Authors' computations using CSA data (Ethiopia, CSA volumes 1, 2, and 3, 2004/2005-2015/2016) and EDRI (2009). Note: Others include rural roads and other capital investments.

FIGURE 3.6 Trends in total factor productivity and output growth, 2004/2005-2015/2016

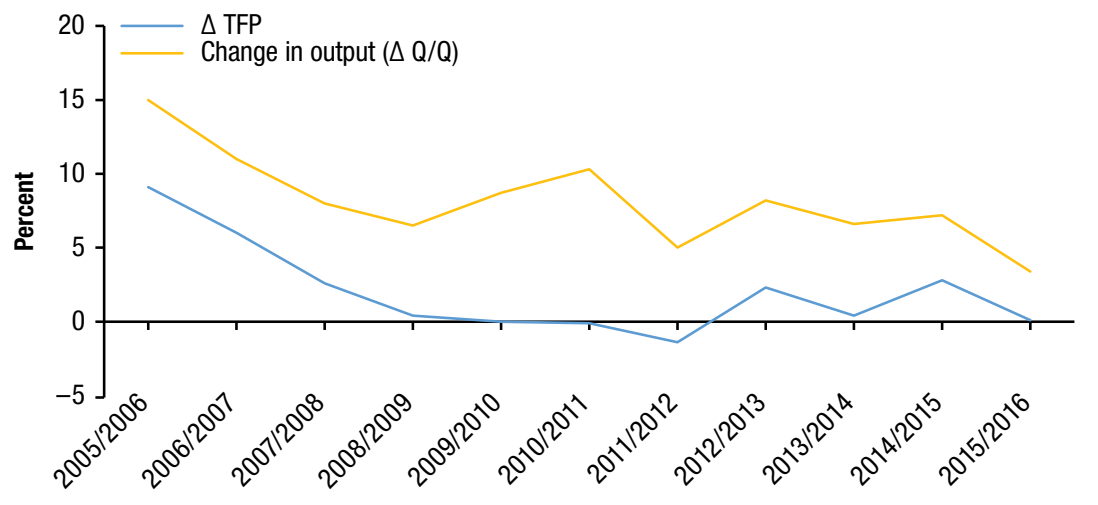

Source: Authors' computations using CSA data (Ethiopia, CSA volumes 1, 2, and 3, 2004/2005-2015/2016) and EDRI (2009).

TFP-increasing technological (nonconventional) inputs such as extension, use of fertilizer and pesticides, investments in roads, and irrigation have increased. The contributions of traditional inputs (land and labor) have also slightly increased or roughly remained the same over these periods.

A number of reasons can be given for this observed dynamic in TFP. First, Berhane et al. (2018) find that the extension system has increased productivity indirectly through its effects on increasing adoption of modern inputs but not directly through its (knowledge transfer) effects on improving 
FIGURE 3.7 Relative contributions of inputs and total factor productivity to output growth (\%)

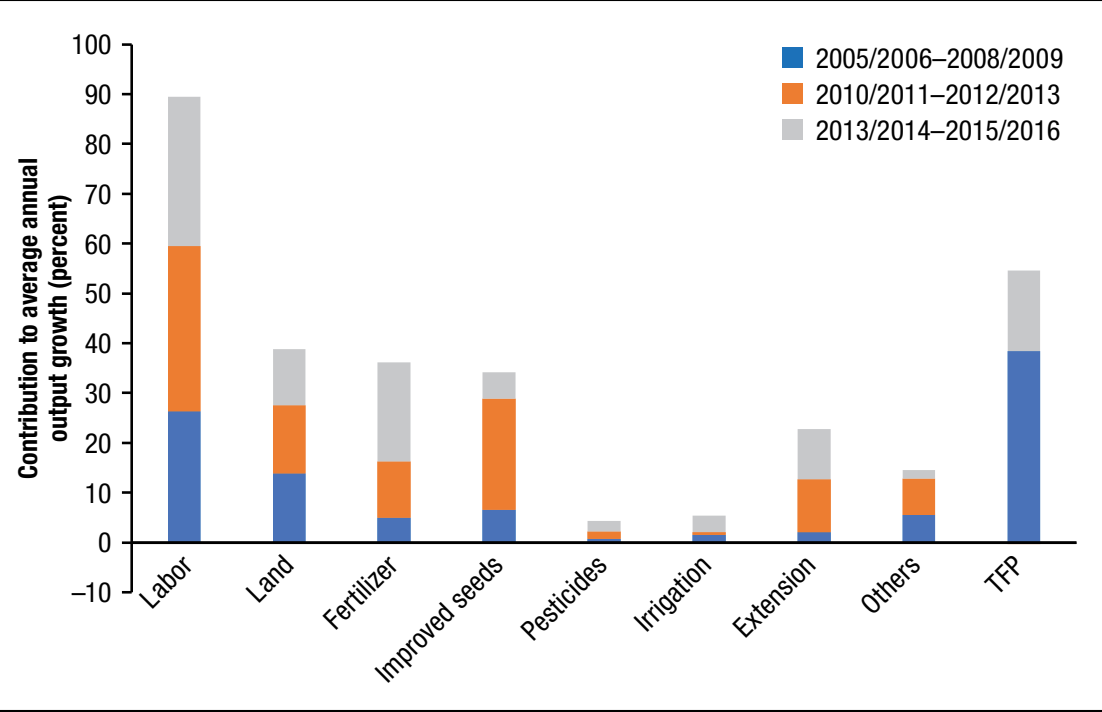

Source: Authors' computations using CSA data (Ethiopia, CSA volumes 1, 2, and 3, 2004/2005-2015/2016) and EDRI (2009). Note: Others include rural roads and other capital investments.

better use of these technologies and modernizing the overall farming systems. ${ }^{8}$ Once the low-hanging fruits in productivity increases (at a rather low base) are exhausted through this basic support, achieving additional productivity (TFP) gains becomes increasingly difficult. Second, Ethiopia's investment on agricultural R\&D as a share of agriculture GDP is one of the lowest even among African peers (Laborde et al. 2018). As a result, the link between research and the extension system is weak (Berhane et al. 2018), limiting longterm productivity gains ultimately leading to declining TFP. Third, although significant capital investments have been made on roads and other physical infrastructures in recent years, poorly developed value chains and weak integration with central markets for a number of crops prevent farmers from realizing the full productivity potential - as in the form of changing production organization in farming- of such investments (Laborde et al. 2018). Fourth, despite the initial focus on agriculture-led development and the commitments

8 Ethiopia has put in place one of the largest extension systems in Africa (Davis et al. 2010). However, the system has remained largely under resourced and poorly linked with research, and as a result has rather focused more on channeling of modern inputs and less on providing knowledge-based support to farmers (Berhane et al. 2018). See also Abate et al. (2019) and Makhija et al. (2019) for discussions of video-mediated agricultural extension in Ethiopia. 
to invest in agriculture in the early years, there has been a recent slowdown in Ethiopia's efforts to support agriculture (as evidenced by the relative budget decline as share of GDP in recent years and the shift in focus to manufacturing and infrastructure sectors) (Laborde et al. 2018).

\section{Sources of Productivity Growth and Implications for the Future}

The sources of recent productivity growth in Ethiopia's crop agriculture cannot be explained without understanding the initial conditions. Prior to the 1990s, Ethiopia's crop agriculture was characterized by a prolonged period of misguided policies that led to shrinking production, both in terms of cropped area and input intensity (Benin and Nin-Pratt 2016). The sector transited through a period of recovery and turnaround after major reforms following the change of government in the 1990s. Subsequent policies have had significant implications to growth in this sector. As such, the growth episodes and sources of growth following these reforms can be characterized in three periods (see also Mellor 2014): the period of "intensification of traditional practices" immediately after the reform and early policy efforts to reduce poverty; the period of "modern input expansion" following the agriculture-led development strategy of the 1990s and subsequent major investment plans, namely the Plan for Accelerated and Sustained Development to End Poverty (PASDEP); and the most recent years of the Growth and Transformation Plan (GTP) (Ethiopia, MoFED 2006, 2010). A centerpiece in the PASDEP was intensification of smallholder agriculture through tailored interventions to promoting technology packages of seed and fertilizers, supported by credit and field-level extension system and a network of demonstration centers. The GTP also deepened the focus on smallholder agriculture with, among others, additional emphasis on commercialization of high-value crops, support to smallholder irrigation, and better use of groundwater (more on this below).

The policy change in the early 1990 s contributed to an impetus for recovery and turnaround, which led to a realization of early high growth. In other words, the peace dividend gave rise to deployment of more and better-quality crop husbandry practices, as in the form of increased labor intensity in land preparations, weeding, and harvesting. This was low-hanging fruit that led to an early growth momentum in the late 1990 s to early 2000s, attained through intensification by using traditional labor-intensive practices using family labor on small farms (Mellor 2014). This sustained later growth, which was accompanied by strong public sector support of more than 10 percent of 
public spending toward agriculture, among the highest rates of spending on the continent.

In 1995 an ambitious frontline extension system was launched focusing on increasing cereal productivity through participatory demonstration and training (Berhane et al. 2018). In the early years the extension system, among others, was tasked with the coordination and delivery of packages of modern technologies for smallholders, mainly improved seeds and fertilizers along with financial services tied with these inputs. ${ }^{9}$ The system also served as the nearest government agency to smallholders, providing series of meetings, motivational trainings, and on-farm demonstrations.

These efforts led to increased use of fertilizers, improved seeds, and pesticides, and to husbandry intensification, which ultimately resulted in increases in land use efficiency. Increased gains from land efficiency also meant that farmers were incentivized to expand land, including to marginal grazing areas that were not attractive before. A combination of these two factors-mainly efficiency change due to intensification of traditional practices and expansion of land under cultivation-contributed to productivity increases in the early years (Bachewe et al. 2018). For example, Benin and Nin-Pratt (2016) decompose TFP growth in Ethiopia for the period 1985-2012 (the closest period to this discussion) and find that more than 90 percent of TFP in this period was explained by efficiency change, suggesting that technical change contributed little to agriculture growth during this period.

In the remainder of the chapter, we look in detail at a number of input factors deemed important for crop productivity growth. We discuss agricultural extension and R\&D spending, chemical fertilizers, improved seeds, agrochemicals, access to credit, irrigation, mechanization, and implementation capacity.

\section{Agricultural Extension and R\&D Spending}

The productivity gains in the 1990s and the potential productivity gap motivated further investment in agriculture in the early to mid-2000s. Two consecutive ambitious five-year plans-namely PASDEP I (2006-2010) and PASDEP II (2011-2014) — were launched to, among other goals, sustain and accelerate productivity growth in agriculture. Technology packages were designed and introduced under the Participatory Demonstration and Training Extension System (PADETES) and implemented through a national agricultural intervention program. This has set forth the beginning of a large

9 Berhane et al. (2018) provide a detailed description of Ethiopia's extension system and its operations. 
extension system where frontline extension agents are deployed to every kebele specializing in agronomic management practices. ${ }^{10}$ Extension agents follow a "training and visit" type of extension approach, providing basic agronomic support and information dissemination. This is backed by a team of "subject matter specialists" stationed at the district level, tasked with providing technical support and supervision of the extension agents (for details, see Berhane et al. 2018). The PASDEPs have focused on an ambitious increase of the extension agents, deploying 63,000 of them to reach millions of farmers throughout the country. Figure 3.8 shows that both the number of smallholders reached and the cultivated area that benefited from the extension system tripled between 2004/2005 and 2015/2016. This system is hailed as one of the largest and most extensive public extension systems in Africa, at least in terms of extension agent-farmer ratio. In 2010 the extension agent-farmer ratio was estimated at one agent per 476 farmers-equivalent to 21 extension agents per 10,000 farmers (Davis et al. 2010).

Comparable figures for Tanzania stood at 2,500 farmers per one agentthat is, four agents per 10,000 farmers and 16 agents per 10,000 farmers in China (Davis et al. 2010). By 2016/2017 this estimate for Ethiopia went up to 46 agents per 10,000 farmers. Official records indicate that in 2017 there were around 72,000 extension agents deployed in the country, three to four agents per kebele specializing in crop production, livestock, natural resource management, irrigation agriculture, and veterinary services. Moreover, the country had planned to establish about 15,000 farmer training centers (FTCs), one per kebele, but in 2010 only about 30 percent were fully functional (Davis et al. 2010).

While these are impressive achievements of the extension system, recent studies (see Berhane et al. 2018) suggest that the system is weak in terms of the technical and knowledge support it offers to farmers, partly due to the sheer size it covers, making it difficult for frontline agents to reach farmers all over the country, characterized by complex and diverse problems. Key issues in the extension system are the lack of resources for extension agents, that they are not sufficiently trained to provide the required technical support, and that they are overburdened by nonagricultural activities limiting the amount of time left for technical support (Berhane et al. 2018). An important factor is also that the system is poorly linked with national agricultural research centers whose incentive structures remain misaligned to provide the required knowledge solutions to farmers.

10 Kebele is the lowest administration unit, composed of a few villages in Ethiopia. 
FIGURE 3.8 Number of smallholders and cultivated area covered with extension package and number of beneficiary farmers

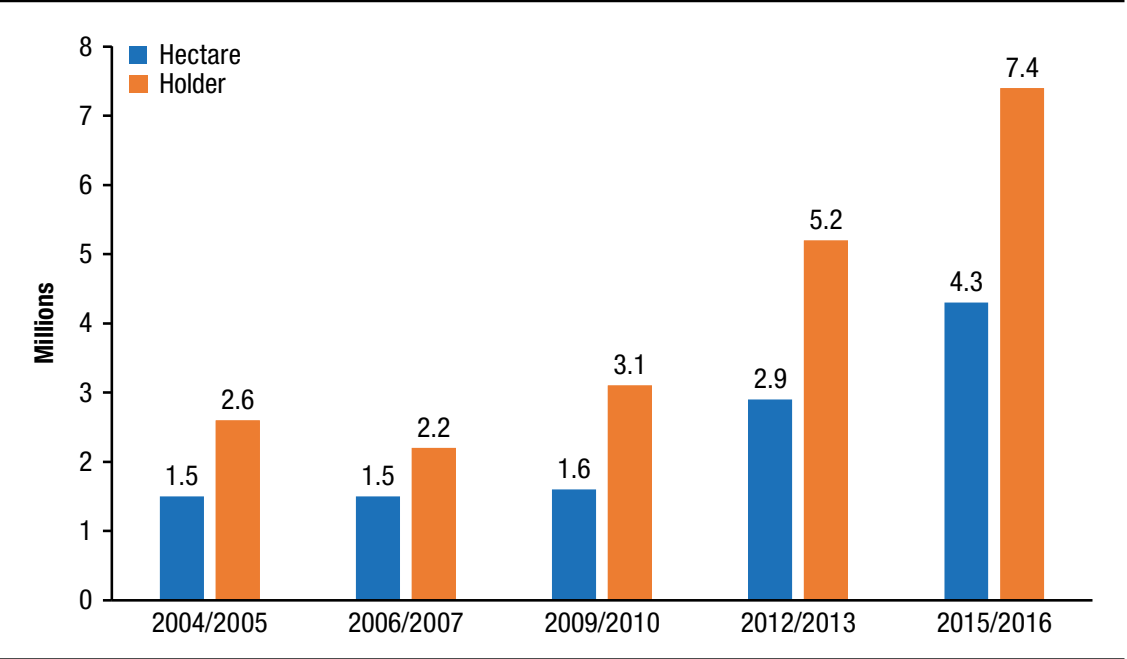

Source: CSA annual Agricultural Sample Survey household-level data (Ethiopia, CSA 2004-2016).

A recent study finds that access to the extension system significantly contributed to the increased adoption of modern inputs such as chemical fertilizers and improved seeds through disseminating basic agronomic information to farmers but even more so through persuading farmers to adopt technologies largely channeled through government parastatals (Berhane et al. 2018). In other words, the impact on productivity has not been as expected mainly because the extension system has largely focused on facilitating the distribution of modern inputs and less on disseminating new knowledge due to its poor links with research centers. Thus extension has played an important role in expanding fertilizers and improved seeds and basic agronomic knowledge-hence it brought about some efficiency change, but not to the extent of bringing about technical change needed to move the frontier outward. Owing to this, despite improvements, production systems remain predominantly traditional. A key reason is seemingly the poor feedback loop between extension agents, farmers, and knowledge centers (Berhane et al. 2018). ${ }^{11}$

11 In other words, an extension system poorly linked with research centers means that the real value of extension messages conveyed by agents to farmers got less nuanced and the "effect has wore off" over time (Krishnan and Patnam 2014; Berhane et al. 2018). 
These findings appear consistent with the national productivity trends presented earlier, suggesting that productivity growth rates are likely to slow down if the system is not revamped to provide additional technological and scientific support to help farmers advance their farming systems out of current traditional practices.

Ethiopia has also invested a significant amount of resources on agricultural R\&D. With inflation-adjusted spending increase of 60 percent between 2011 and 2016, Ethiopia is among the top six SSAs that invested in R\&D (Beintema and Haregewoin 2018). The number of agricultural researchers per 100,000 farmers has more than tripled between 2002 and 2014 (from 2.5 researchers per 100,000 farmers in 2002 to about 8 in 2014) and has seen one of the fastest increases (13.5 percent per year) in SSA, although still from a rather low-base as compared to other couturiers below the Sahara. Excluding university research institutes, there are about 62 federal and regional agricultural research centers, well spread across the various agroecologies in the country (Berhane et al. 2018). ${ }^{12}$

An important constraint often cited is that national research centers are underfunded, leaving them at a disadvantage internationally and, as a result, vulnerable to high staff turnovers. Ethiopia's investment on $R \& D$ as a share of agricultural GDP has declined in recent years (mainly because the research system has expanded without proportional change in R\&D spending), making it one of the bottom nine countries in SSA (Figure 3.9). In 2014, Ethiopia's spending on R\&D was only 0.24 percent of agriculture GDP.

In addition, despite recent rapid growth rate, Ethiopia still has one of the lowest number of researchers with PhDs in Africa south of the Sahara relative to its total number of researchers. Moreover, poor incentive systems, lack of proper coordination between centers, and misalignments in the researchextension-farmer feedback loops have rendered such investments ineffective (Deneke and Gulti 2016; Kassa et al. 2016; Davis et al. 2010). These declines in public spending in Ethiopia's R\&D are consistent with the general contraction of the share of agriculture expenditures to GDP in recent years but the decline is more prevalent for agriculture (and water), which declined by about 6 percent between 2007/2008 and 2012/2013 (World Bank 2016). Some see this decline as a slowdown of the focus on agriculture in recent years (for example, see Laborde et al. 2018).

12 Indeed, some of the local research has helped generate improved local varieties, including on crops that are unique to Ethiopia (teff) and that receive limited international funding resources (Minten et al. 2013; Minten, Taffesse, and Brown 2018). 


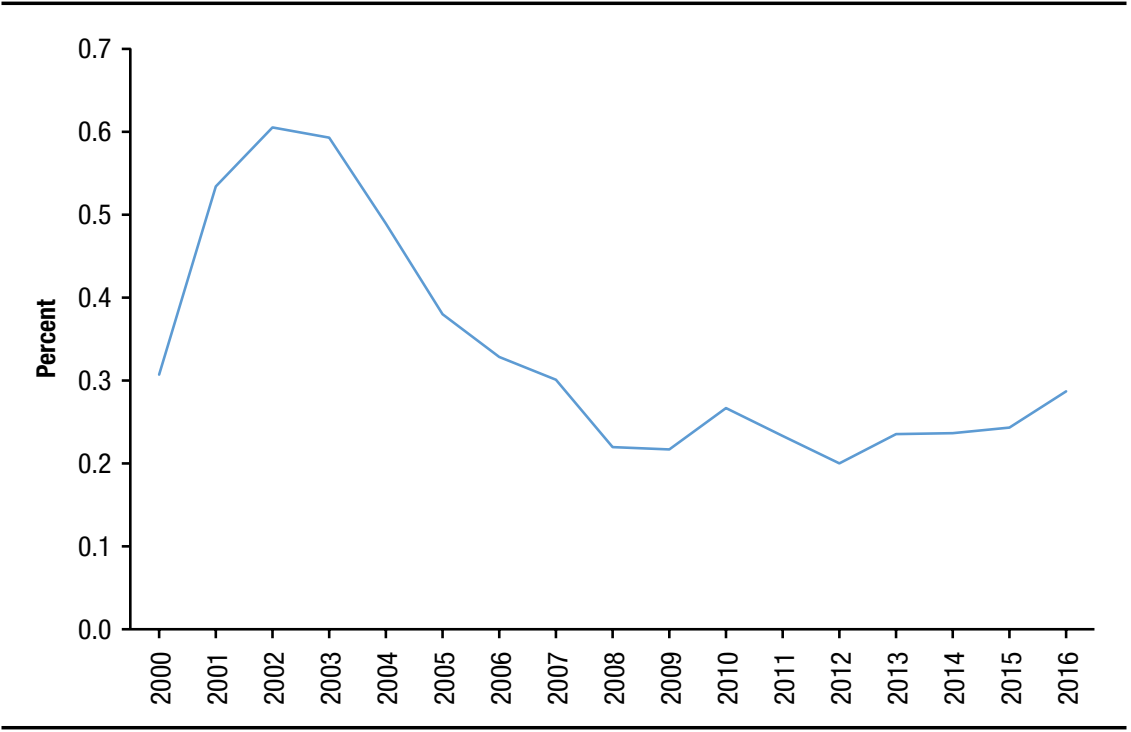

Source: ASTI (2019).

\section{Chemical Fertilizers}

More than 50 percent of agricultural productivity gains during the Green Revolution in Asia was due to an increase in adoption rate of inorganic fertilizer alone (Hopper 1993; Sheahan and Barrett 2014). In view of the same objective, Ethiopia's fertilizer imports and use have dramatically increased in the past decade. Average annual fertilizer imports have jumped from 346 thousand metric tons in 2004/2005 to 778 thousand metric tons in 2012/2013 - an increase by 124 percent; and fertilizer use by smallholders has also increased by 144 percent over the same period (Bachewe et al. 2018). Fertilizer use has increased for all crops despite variations in application rates and proportion of area fertilized by crop types (for details, see Bachewe et al. 2018). However, consistent with the food security focus in production, most fertilizer use has been on cereals.

According to CSA reports, 4.7 million holders ( 46 percent) growing cereals used fertilizer in $2004 / 2005$, which grew (by 76 percent) to 10.1 million holders in 2015/2016. Most of the chemical fertilizers are geared toward cereals. Cereal area applied with fertilizer-which nearly doubled during the same period from 2.7 million hectares in 2004/2005 to 5.2 million hectares in $2015 / 2016$, or an increase from 36 percent to 53 percent of the total cereal 
area-accounted for at least 91 percent of total fertilized area in all years except in 2009/2010.

Figure 3.10 and Table 3A.1 present fertilizer intensity trends by fertilizer types (urea, DAP, urea and DAP, NPS, and NPS and DAP) in quintals per hectare of areas covered with these nutrient types for the period 2004/2005 through $2017 / 2018 .{ }^{13}$ Intensity of areas covered by all fertilizers has increased from 64 kilograms per hectare in 2004/2005 to 148 kilograms per hectare in 2017/2018 - an increase by about 131 percent. On those areas covered with urea and DAP, it has increased by 51 percent from 134 kilograms per hectare in 2004/2005 to 203 kilograms per hectare in 2017/2018. Intensity has also increased for those using only DAP (by 62 percent) and for those using only urea (by 34 percent) for the same period. Compared with the traditional urea and DAP blends, the recently introduced blends of NPS as well as NPS and DAP seem to enjoy higher use.

Despite the sharp increase in fertilizer imports and use, application rates remain significantly below recommended rates (of above 200 kilograms of fertilizer per hectare) with only 64 to 162 kilograms per hectare of fertilizer applied on average. Using the Agricultural Growth Program (AGP) data, Berhane and Assefa (2020) calculate that cereal fertilizer yield response in Ethiopia appears to be relatively profitable when more fertilizer is applied (on average, application of 300 kilograms of urea and DAP gives 2,100 kilograms of maize, 1,800 kilograms of wheat, or 1,300 kilograms of teff) (Figure 3.11). This is roughly above 4:1 ratio of additional grain per kilogram of fertilizer. In the same period, Bachewe et al. (2018) using the same data, report that the output-fertilizer (for the same five main cereals) ratios were twice as high in 2012 than in 2014. This implies that cereal productivity can be further enhanced by increasing fertilizer intensity to internationally comparable levels of 250 kilograms per hectare to 300 kilograms per hectare and beyond.

Figure 3.12A and Figure 3.12B further provide comparative fertilizer intensity figures per arable land available in each selected African and Asian

13 Note that figures reported based on CSA data are relatively higher than those from other sources (see, for example, Figure 3.11) because CSA fertilizer use is over fertilized area while those in Figure 3.11 are calculated for total arable land use in the country. The latter is only suggestive as arable land can significantly vary by size of country. Fertilizer application rates per hectares of applied land obtained from other household surveys (for example, AGP datasets) are comparable to the CSA figures. The latter are in the order of 100 to 133 kilograms per hectare (see Berhane, Bachewe, and Minten 2018). 
FIGURE 3.10 Fertilizer use trend in Ethiopia, 2004/2005-2017/2018 (quintals per hectare of fertilized area)

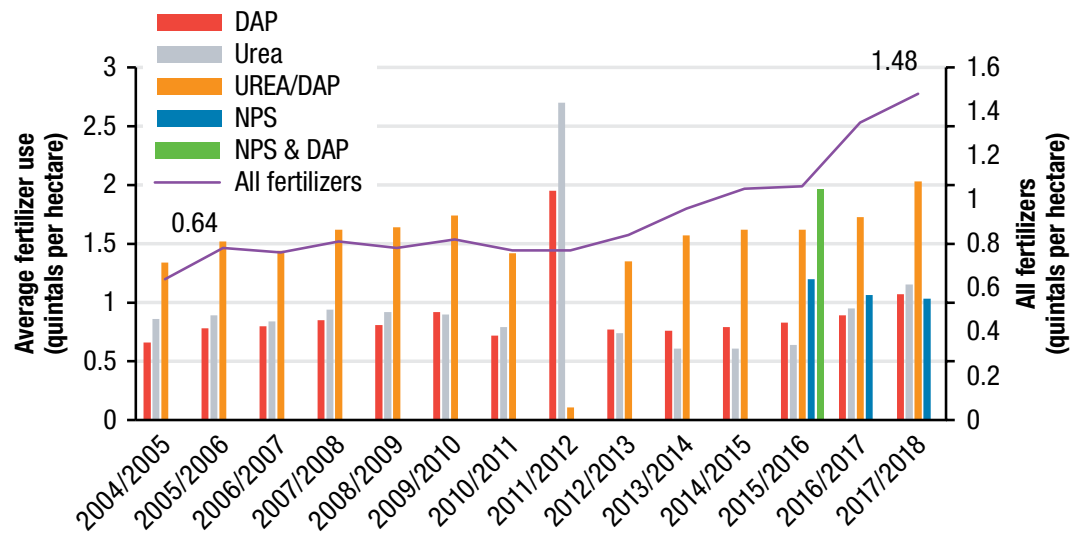

Source: Authors' computation using CSA annual reports (Ethiopia, CSA volume 3, 2004-2018).

FIGURE 3.11 Trends in yield responses to levels of fertilizer intensity for selected crops in Ethiopia

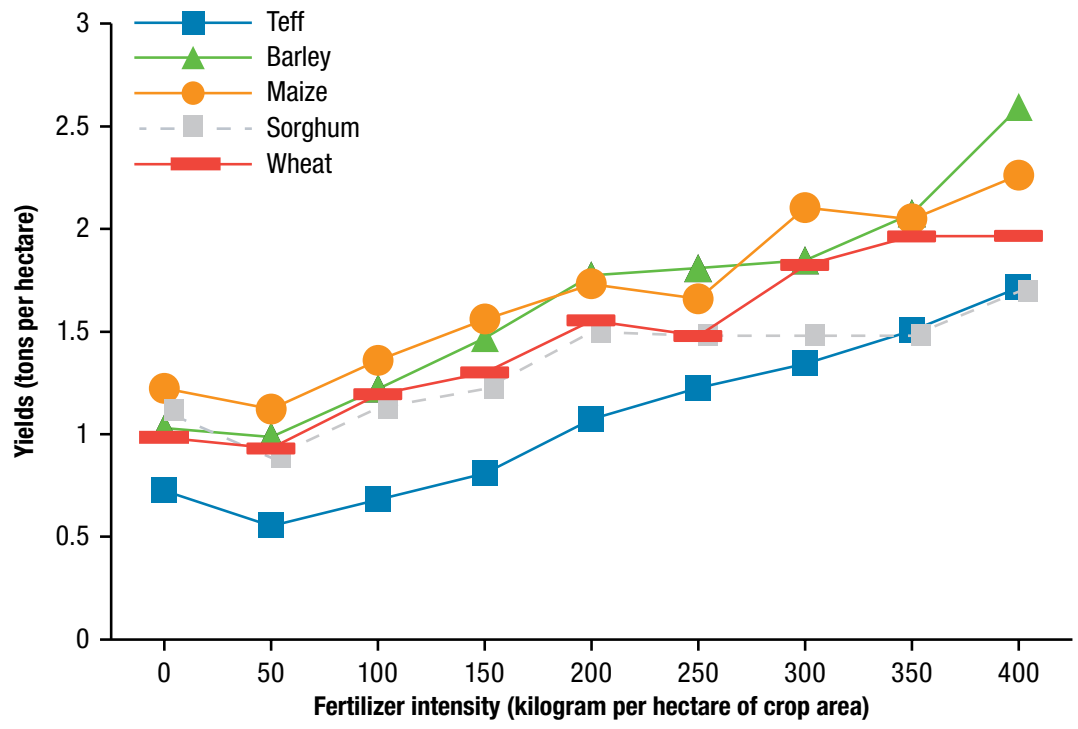

Source: Berhane and Assefa (2020), using the Agricultural Growth Program dataset (USAID 2013). 
FIGURE 3.12A Average fertilizer applied to arable land for selected Africa south of the Sahara countries (kilograms per hectare)

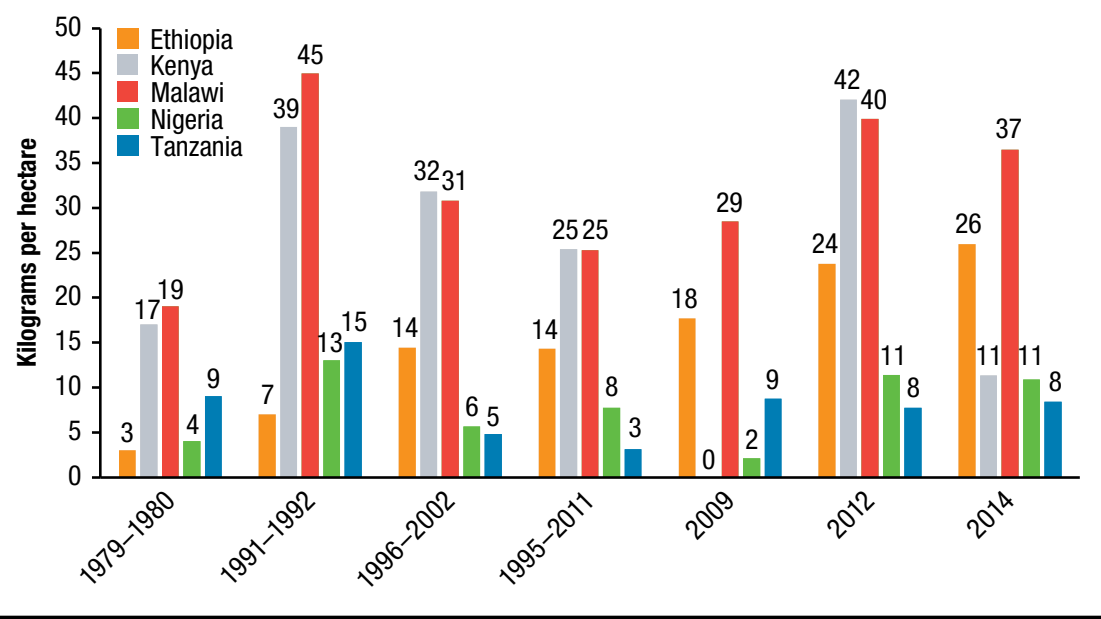

Source: Authors' calculations based on data from ourworldindata.org 2014.

FIGURE 3.12B Average fertilizer applied to arable land for selected Asian countries (kilograms per hectare)

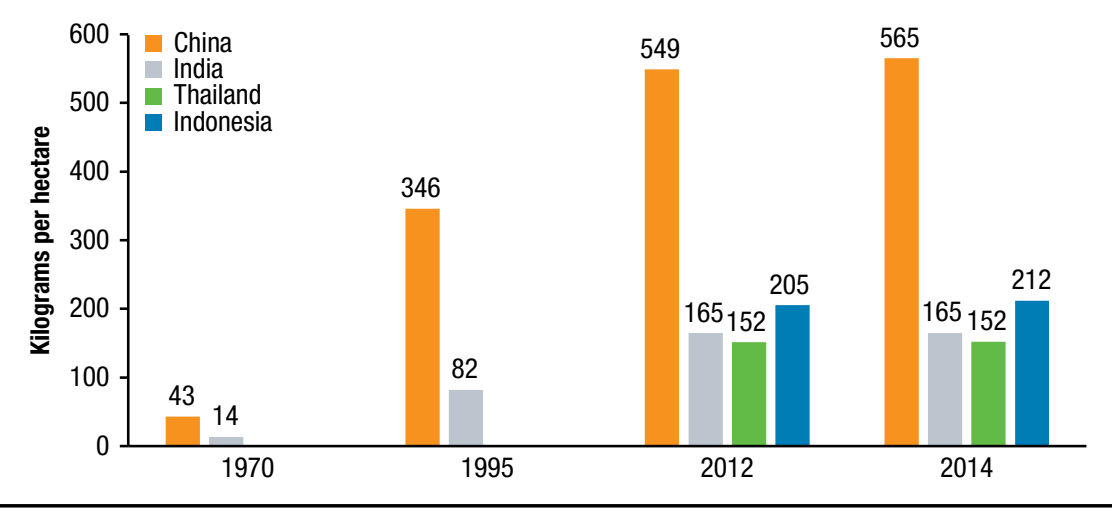

Source: Authors' calculations based on data from ourworldindata.org, 2014. 
country respectively. ${ }^{14}$ Compared with the selected SSA countries, Ethiopia's performance in applying fertilizer per arable land available is above the rest of SSA countries, except for Malawi, partly because of its large fertilizer subsidy program in recent years (Ricker-Gilbert, Jayne, and Chirwa 2011). This is consistent with findings by Sheahan and Barrett (2014), who indicated that Ethiopia's average kilograms of fertilizer per hectare application rate is slightly above SSA's average. Ethiopia's average application rate in 2014-at 26 kilograms per hectare-was slightly higher than the Asian average of 24 kilograms per hectare at the beginning of the Green Revolution in the 1970s but much lower than that of China-at 40 kilograms per hectare-in that period. Moreover, Ethiopia's average application rate in 2014 is also slightly below India's (82 kilograms per hectare) and China's (346 kilograms per hectare) performance in 1995. In 2014, Ethiopia's average fertilizer use per hectare of arable land is sixfold lower than that of India and Thailand, eightfold lower than Indonesia, and twenty-two-fold lower than that of China (Figure 3.12B). This shows that Ethiopia still has way to go in fertilizer intensification compared with Asia's recent performance in this regard.

While fertilizer adoption improved significantly over the past decade, there are seemingly a number of important constraints to adoption by Ethiopian farmers: (1) lack of availability of a variety of nutrient blends suitable for all soil types given the diversity of soil types in Ethiopia is one important constraint (for example, Croppenstedt, Demeke, and Meschi 2003; IFDC 2015); (2) rainfall variability, localized droughts, and lack of moisture remains another of the challenges facing fertilizer profitability and response rates influencing farmers' risk behavior in using fertilizers (for example, Alem et al. 2010); (3) inefficient logistics, bureaucratic structures, and unpredictable fertilizer-credit supply systems further constrain timely access to fertilizers (Rashid et al. 2013). ${ }^{15}$

\section{Improved Seed}

Access to improved seed varieties is a key challenge of agricultural transformation in Africa, largely due to the complexities involved to develop the sector.

14 Note that figures reported in Figures 3.12A and 3.12B are kilograms per total hectares cultivated (and not comparable to those in Figure 3.10, which reports kilograms per fertilized hectares). These figures need to be interpreted cautiously as fertilizer use per available cultivable land (not all fertilized) is not an accurate measure of intensity because cultivable land varies by size of country. Nevertheless, in the absence of other comparable accurate measures available, these figures provide some insights into cross-country comparisons of fertilizer intensity.

15 See Rashid et al. (2013). 
A key challenge in Ethiopia's seed sector is that it has remained predominantly public sector-dominated, restricting potential involvement by the private sector (Alemu et al. 2007; Spielman et al. 2010; Alemu, Rashid, and Tripp 2010). Nevertheless, Ethiopia has shown progress in this sector as well. Over the decade discussed in this chapter, the number of improved seed varieties released to farmers has increased rapidly due to significant public investments in local capabilities of research and seed multiplication structures. Official data from the public seed enterprises and the Ministry of Agriculture shows that certified seed production has jumped more than five-fold over the past decade (ATA 2017a). Bachewe et al. (2018) indicate that release rates for improved seed varieties have been particularly dynamic for wheat but lower for other crops. In the past ten years about 50 varieties of wheat and at least 20 varieties of each for maize, barley, and teff have been released by Ethiopia's national agricultural research institutes (ATA 2017a).

Reliable national data on use of released varieties is scarce partly because of the challenges to account for reused varieties in national surveys. Reported adoption rates of improved seed varieties by farmers are low overall. ${ }^{16}$ Using the CSA data, Table 3.4 reports total cultivated area and percentage of land under purchased improved seeds. The proportion of farmers using purchased improved seeds (and the area covered by improved seeds) has seen significant improvements, with more than a doubling noted for teff, barley, wheat, and maize over the past decade. Large increases in the proportion of farmers adopting purchased improved seeds are noted particularly for maize producers. This is consistent with the yield increases of all crops presented in Figure 3.1, suggesting that some of the yield improvements, mainly maize (followed by wheat) is also associated with the use of improved verities. Abate et al. (2015) show that increased use of improved maize varieties has greatly contributed to doubling of maize production in Ethiopia in the same period, and they have pointed out that despite these changes, opportunities for further maize yield growth still exist in Ethiopia.

The other increases are from a rather low base in 2004/2005 and remain very low both in terms of area and the proportion of land covered by improved seeds. Several factors contribute to this poor performance.

First, despite the large number of seed varieties released by the formal sector, only few of them are adopted and commercialized by seed enterprises and hence many did not reach farmers. A key reason is that variety development

16 Recent studies using DNA fingerprinting to identify reuse rates suggest that reported use of released varieties may underestimate actual improved seed use rates (Yirga et al. 2016). 


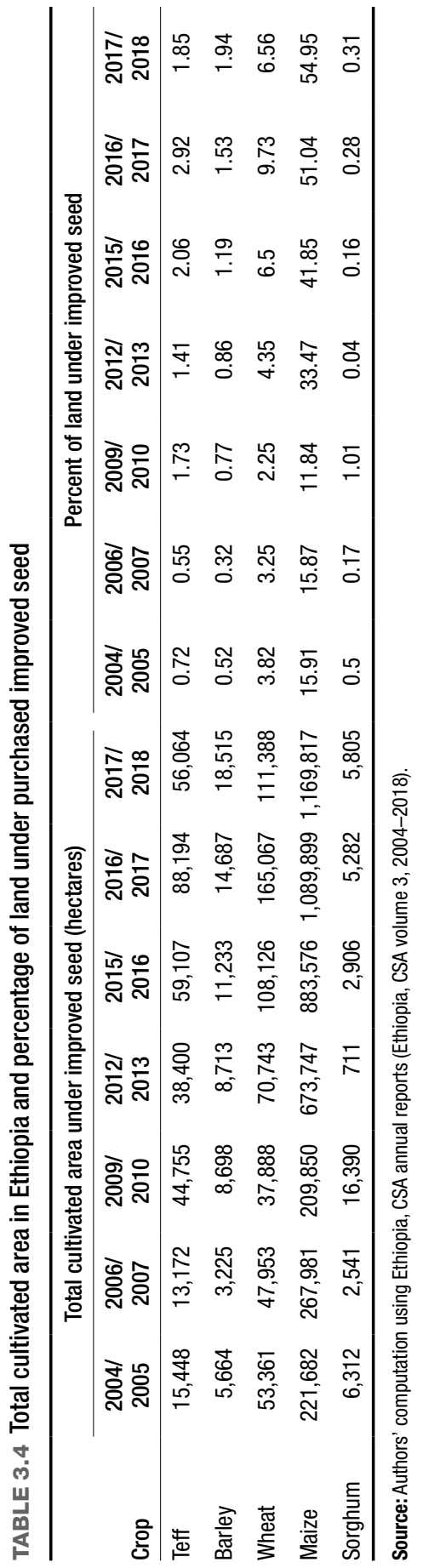


is not demand-driven, making it unsuitable to many agroecological contexts, offering low value for money to farmers. Key structural bottlenecks are a low level of national breeding research quality and poor alignment of research incentives with the core transformation agenda. In other words, recent expansion in the quantity of seeds supply has come at the expense of quality deterioration. For instance, only two hybrid maize varieties released about 20 years ago account for about 95 percent of all hybrid maize varieties adopted by farmers (Ali, Deininger, and Harris 2019). Note, however, that recent evidence from DNA fingerprinting suggests that most farmers do not reliably identify the varieties they plant (see also footnote 16). Second, despite significant recent public investments in plant breeding research and multiplication, low level of coordination between research centers themselves and the extension system as well as poorly organized distribution mechanisms remain key bottlenecks. More specifically, a centralized seed need assessment and supply system executed by a lengthy bureaucratic system extending from the Ministry of Agriculture to public seed enterprises and cooperatives renders the seed sector value chain ineffective (ATA 2010, 2017b). Third, while many studies indicate improved seeds are profitable when adopted with other complementarity technologies including fertilizers and irrigation (for example, Abay et al. 2018), such synergistic values are low in Ethiopia due to limited access to irrigation infrastructures and optimized fertilizer blends.

\section{LAND TENURE}

In Ethiopia land is state owned, and holders are given only usufruct rights, including the right to rent and sharecrop it for a fixed number of years. Subsequent policies introduced to discourage distress leasing of land and associated transaction costs have further complicated land rental markets (Deininger et al. 2008; Ghebru, Holden, and Tilahun 2019). In addition, with increasing population pressure, the youth and vulnerable groups are faced with increased constraints to access land (Headey, Dereje, and Taffesse 2014; Gebrehiwot and Holden 2019). Relaxing land rental market restrictions and delinking land user rights from land use would encourage farmers with small plots, or those who do not have enough resources to operate the land, or those who have skills and resources that could more efficiently be applied in other sectors, to transfer their use rights to potential tenants (Ghebru 2010; Holden, Otsuka, and Deininger 2013; Bezu and Holden 2014; Haddis 2013).

Moreover, formalizing land rights are often considered as avenues to land tenure security and increases in land market participation (Holden, 
Deininger, and Ghebru 2007). A large-scale land certification program was set up in the country in the 1990 s to ensure more secure land property rights. This land certification program has been one of the largest, cheapest, and fastest in Africa (Deininger et al. 2008) - it is estimated that about half of farmers in the main four regions benefited from this certification program (Ghebru, Koru, and Taffesse 2016). While land remains the property of the state, the certificates have ensured more secure property rights, since they are found to encourage higher investments, more land rental market activity, higher productivity, and improved food security (Holden, Deininger, and Ghebru 2007; Deininger, Ayalew, and Alemu 2011; Ghebru and Holden 2013; Melesse and Bulte 2015). As this land certification program in most areas happened before the period under study here, it might not have directly contributed to increased productivity in the past decade, but it seems that these more secure property rights helped to provide the necessary required conditions for the increase in agricultural productivity seen afterward.

However, a number of issues are still problematic for land tenure. For example, while there are laws to help protect landowners, these laws are in practice sometimes not effective as some of the landlords see rental markets are the most efficient way to use their land (Holden and Ghebru 2016). Despite all these positive developments in the past two decades, going forward, restrictions in land markets and poor land transactions remain key challenges of increasing agricultural productivity in Ethiopia.

\section{Irrigation and Mechanization}

Ethiopia's crop agriculture remains predominantly rainfed. In the absence of irrigation, given climate change and erratic rainfall, poor moisture conditions together with degraded soils remain a binding constraint to increasing productivity in Ethiopia. With frequent droughts in recent years, agriculture has become increasingly risky, making increases in productivity difficult. Studies indicate that irrigation can double average land productivity and at times provide 90 percent higher yields than comparable rainfed land (Fuglie 2008; Fuglie and Rada 2013). Public investments in irrigation structures have played pivotal roles in Asia's Green Revolution, particularly in India (Evenson and McKinsey 1999). Proclaimed as one of the water towers of Africa, Ethiopia is known to have substantial irrigation water potentials from both river basin runoffs ( 12 river basins with an annual runoff volume of 122 billion cubic meters) and groundwater (an estimated 2.6 billion cubic meters to 6.5 billion cubic meters), with 3.7 million hectares of developable land potential for irrigation (Awulachew et al. 2017). 
However, despite recent efforts on advancing small-scale irrigation development, irrigation use remains low even for Africa south of the Sahara (Sheahan and Barrett 2017). Table 3.5 provides total area and percentage of land under irrigation using CSA's annual agricultural household sample survey. It indicates that land under irrigation (only meher season) for some crops has slightly increased over the decade, but the total area under irrigation has remained the same and is very low compared to other countries, for example China (37 percent) and India (32 percent) in 1995 (Rosegrant and Hazell 2000). Estimates based on CSA's agricultural household survey during the meher season shows land area under irrigation at 181,281 hectares in 2017/2018 (see Table 3.5). Unfortunately, CSA lacks good data on use of irrigation in the off-season, and these estimates also exclude the large-scale commercial farms. The meher estimates are therefore underestimates of access and use of irrigation. The government estimates that 2.8 million hectares are irrigated (Ethiopia, NPC 2018). Recent irrigation area identification mapping exercises using satellite information systems with validations on ground inventorying estimate irrigated area at 1.35 million hectares $(7$ percent of total area)-lower but closer to the official figure but significantly higher than the CSA estimate for the meher season (Kiran et al. 2018).

Ethiopia's Growth and Transformation Plan II (GTP II) sets out ambitious irrigation development plans for 2016/2017 and beyond: undertake small-scale irrigation on 2.94 million hectares; undertake study and design works on 142.8 thousand hectares; and carry out irrigation structures on 162.2 thousand hectares of land. Official reviews in the first year indicate lower performance than expected due to capacity and budgetary constraints (Ethiopia, NPC 2018). Anecdotal evidences also suggest that poor capabilities in irrigation and water resource management remain hurdles to sustainability of existing structures.

While use of mechanized farm tools can play critical transformative roles through increasing land and labor productivity (Binswanger and Rosenzweig 1986), owing to these low levels of irrigation and overall traditional farming practices, use of mechanized farm equipment remains low and Ethiopia's agriculture relies still heavily on animal-traction and labor (Berhane et al. 2017). Berhane et al. (2017) indicate despite recent increases in imports of agricultural machines, farm-level uptake of agricultural mechanization in Ethiopia remains low: fewer than 1 percent of plots are plowed with a tractor. They document, on the one hand, that the use of machines in agriculture is likely to increase as costs of labor and animal traction are recently on 


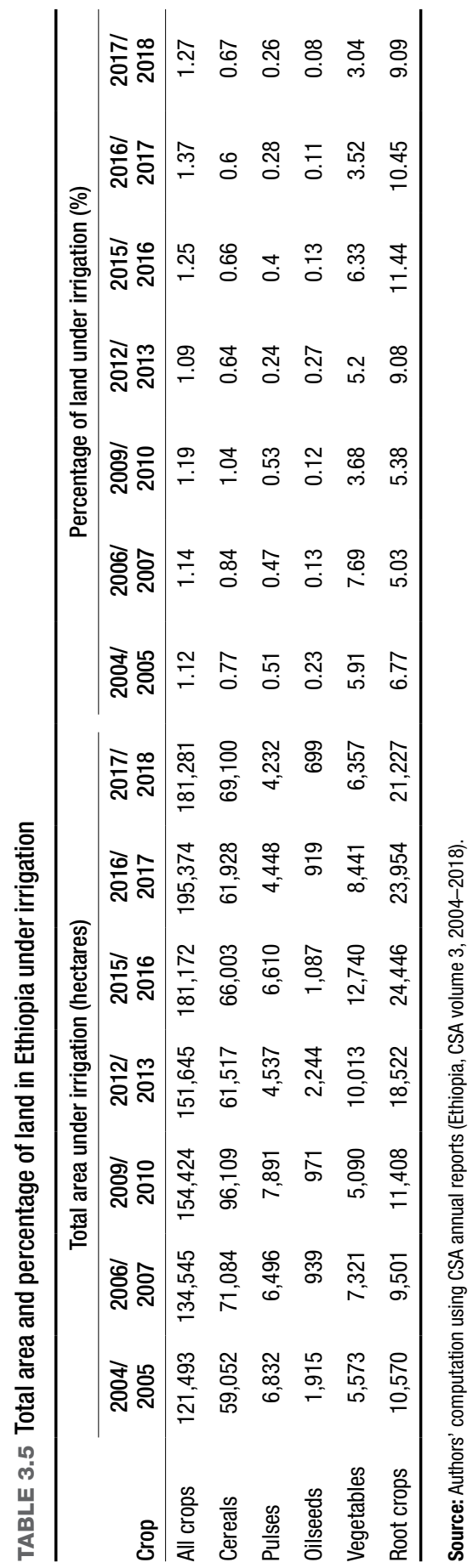


the rise and that, on the other hand, increasingly fragmented plots and small farm sizes, diversity of crops, difficult terrain, credit, and foreign exchange constraints prevent modernization via agricultural mechanization. As such, it seems that important synergistic complementarities between use of modern farm tools and irrigation observed in Asia's Green Revolution and elsewhere are yet to be exploited to sustain recent increases in agricultural productivity in Ethiopia.

\section{Credit}

Lack of adequate access to credit and other financial services is often considered as one of the limiting factors to increase productivity in agriculture. Following the worldwide movement on rural financial markets and the desire to increase agriculture productivity in the past decade, Ethiopia's rural credit market development has received significant attention over the past two decades.

Several government-affiliated and semiprivate microfinance institutions as well as member-based financial cooperatives have flourished throughout the rural areas of Ethiopia in recent years, mobilizing an unprecedented amount of savings and loans, serving (but not limited to) millions of Ethiopian rural households (Berhane and Abay 2019). While rigorous studies on impacts of credit on productivity in Ethiopia are limited, the evidence suggests that eliminating access to credit constraints could increase productivity by about 11 percent (Ali and Deininger 2014) and reduce poverty (Berhane and Gardebroek 2011). However, Berhane and Abay (2019) indicate that despite the enormous expansion in rural financial services, mainly credit, a vast majority of rural households remain underserved, with only 6-10 percent of households participating in credit uptake in 2013 and 2016 (Berhane and Abay 2019).

A critical question for policymakers is therefore given the rapid expansion of financial service providers-mainly loans - to rural areas, why the majority of rural households restrain themselves from taking up these loans. An important point to note here is despite the impressive progress in credit supply, access to credit in Ethiopia is often seen as an intermediate input to other input supply. As a result, rural credit services in Ethiopia are tied up with input supply services, restricting the flexible use of credit to mitigate household liquidity constraints. Berhane and Abay (2019) also point to several demand and supply side bottlenecks preventing households from accessing these loans, including inflexible and the one-size-fits-all nature of credit product designs (for example, the group-lending approach commonly used in 
Ethiopia is not favored by many households given agriculture risk is covariant among group members), high transaction costs of loan processing, inflexible loan size and terms, as well as remoteness. A case in point is that most rural microfinance institutions do not have a mechanism to accommodate emerging "model" farmers that demand increasingly larger loans, which cannot be obtained from formal banks because they lack urban-based collateral formal banks require. This group of farmers simply falls into the "missing middle" in rural credit markets and remains underserved (Berhane and Abay 2019). Clearly, these bottlenecks contribute to the challenges of sustaining recent gains in productivity increases and need to be addressed structurally.

\section{Conclusion}

Ethiopia has made sustained investments in crop agriculture for more than a decade and consistently achieved impressive productivity gains, albeit from a low base. Guided by a strong political will, supported by development partners, to invest in agriculture, Ethiopia has surpassed the 6 percent agricultural growth target set by the CAADP for more than a decade. Between 2004/2005 and 2016/2017, aggregate smallholder crop output has more than doubled, largely attributable to cultivated area expansion and yield growth. In the same period, land under smallholder cultivation has expanded by about 27 percent, 90 percent of which was used for cereals (but later declined and leveled off), and cereal yield has increased significantly, by about 5 percent a year. It is important to note that the analysis focuses on smallholders and does not include recent commercial farm expansion to the lowlands, where productivity levels are not particularly higher than that of smallholders (see Ali, Deininger, and Harris 2019). Despite the high growth rates, compared with other contexts where agricultural transformation has taken root, Ethiopia's yield levels are still rather low and showing signs of slowing down recently.

A key question is whether Ethiopia can sustain growth rates in yield levels and overall productivity to achieve transformation in the face of declining additional cultivable land and recent slowing down yield levels. This chapter has explored the patterns of crop production and assessed the sources of productivity growth so far and what the implications are for future growth. In doing so, the important roles played by critical investments made in the sector and associated structural bottlenecks for future growth are discussed. We present the key findings from the analyses to understand what explains recent output growth and then discuss what needs to be done to sustain future growth. 
Decades of sustained increase in total factor productivity (TFP) - a key measure of long-term agricultural productivity growth-is required to achieve agriculture transformation. How has Ethiopia's TFP fared in the past decade? A stylized growth accounting decomposition of crop output into factors that contribute to its growth in the past decade shows expansion in cultivated land and labor have, respectively, accounted for about 13 percent and 30 percent of Ethiopia's observed crop output growth. Expansion in use of chemical fertilizers, improved seeds, and extension were also important contributors. Moreover, TFP growth has contributed to about 18 percent of output growth in the same decade, suggesting efficiency gains of investments in the production process. However, TFP growth has declined in most recent years (from 38 percent in the beginning of the period to 16 percent in the end of the period), contributing to the recent slowdown in yield growth (Bachewe et al. 2018). Important to note is that the decline in TFP growth rate has continued despite the continued investments on traditionally TFP increasing nonconventional inputs such as extension and chemical fertilizers. The contributions of land and labor inputs have also remained roughly the same, suggesting additional gains in and keeping up with sustained productivity is likely to be increasingly difficult with the status quo. Accelerating TFP growth is a sustainable way of offsetting declining productivity growth due to decelerating input growth, mainly land in the case of Ethiopia (Fuglie 2008).

Although further studies are warranted to understand the sources of growth in view of the recent slowdown in the contributions of TFP and other inputs to agriculture growth, the evidence so far points to the following reasons. First, despite its remarkable success stories in promoting modern technologies and linking farmers to input markets, recent studies emphasize Ethiopia's extension system is overburdened and poorly equipped with the knowledge and skill sets needed to help bring about changes in the production system. Moreover, the system is weakly linked with knowledge centers with poor forward and backward feedback looping between extension agents, farmers, and researchers. The implication is that once the low-hanging fruits in productivity increases through the basic support provided by the extension system are exhausted, achieving additional productivity (TFP) gains would require revising the system to provide much needed technical skills by synching itself with knowledge centers and farmers. A declining yield growth following a similarly (but faster) declining area expansion (see Figure 3.2) also suggests investments in the existing extension system is unlikely to sustain yield growth. Improving this system may require additional investments 
on agricultural $\mathrm{R} \& \mathrm{D}$ and realignment of institutional structures to sustain growth.

Second, despite recent efforts (see, for example, ATA 2017a), critical bottlenecks to sustain productivity increases remain, including inefficient fertilizer markets and logistics and lack of appropriate fertilizer-nutrient blends suitable to each soil type (Zelleke et al. 2010; Rashid et al. 2013; Agbahey, Grethe, and Negatu 2015) on the one hand and poorly organized and inefficient seed markets, poor and supply-driven breeding research, and mismatches between seed multiplication and seed research and farmers on the other (for example, Spielman, Kelemework, and Alemu 2012; Alemu, Rashid, and Tripp 2019). ${ }^{17}$

Third, although significant capital investments have been made on roads and other physical infrastructures in recent years, poorly developed value chains and market infrastructures, weak integration of farmers with central markets, poor and inflexible credit markets prevent farmers from realizing the full productivity potential though changing their farm production organizations.

Fourth, irrigation is one of the weakest links in Ethiopia's agricultural production system. Given increasingly poorer moisture conditions in most parts of the country, water becomes a key hurdle in increasing productivity. Despite recent efforts to expand irrigation capabilities and structures, the progress in this front has remained unsatisfactory. Mechanization and use of labor-saving technologies can also add value through increasing land and labor productivity. However, the sector has several structural challenges (including lack of foreign exchange to import machines, topographical challenges, fragmented plots, lack of enough economies of scale, weak incentives to attract the private sector, and so on) that call for serious attention by different players, including the government.

These key factors have contributed to the general slowdown of TFP in agriculture, seemingly requiring a broad-based investment strategy, given Ethiopia's large and complex farm sector, to address that declining contribution to growth.

17 In 2012, Ethiopia's Agricultural Transformation Agency (ATA) launched a first of its kind initiative on Ethiopia Soil Information System (EthioSIS) that uses extensive soil sampling based on which location-specific fertilizers are recommended. Other similar efforts-including provision of input supply through agrodealers and video-based extension systems-are also being piloted. However, rigorous studies assessing the effectiveness of these experimentations are not yet available, and it is too early to include them in this analysis. See ATA 2019. 


\section{Appendix 3A: Total Factor Productivity and Output Growth}

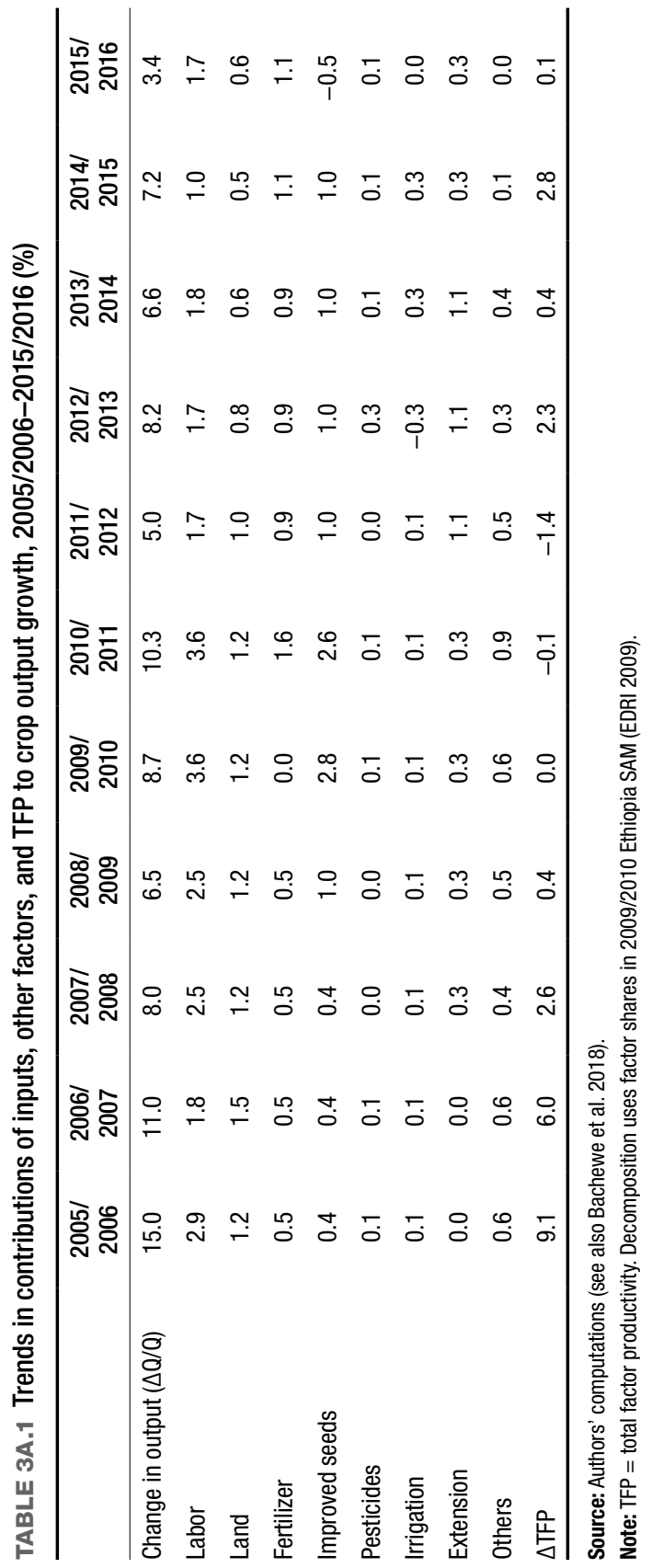


TABLE 3A.2 Trends in relative contributions of factors and TFP as percentage of crop output growth, 2005/2006-2015/2016 (millions of birr)

\begin{tabular}{lrrrcccccr}
\hline Season & Labor & Land & Fertilizer & $\begin{array}{c}\text { Improved } \\
\text { seeds }\end{array}$ & Pesticides & Irrigation & Extension & Others & $\Delta$ TFP \\
\hline $2005 / 2006$ & 19.5 & 8.3 & 3.1 & 2.6 & 0.8 & 0.9 & 0.0 & 3.7 & 61.0 \\
$2006 / 2007$ & 16.7 & 13.8 & 4.2 & 3.5 & 1.1 & 1.3 & 0.0 & 5.1 & 54.4 \\
$2007 / 2008$ & 31.1 & 14.9 & 5.7 & 4.8 & 0.5 & 1.8 & 3.7 & 5.5 & 32.1 \\
$2008 / 2009$ & 38.3 & 18.3 & 7.0 & 15.4 & 0.6 & 2.2 & 4.5 & 7.6 & 6.1 \\
$2009 / 2010$ & 41.4 & 13.6 & 0.3 & 31.5 & 1.1 & 1.6 & 3.3 & 6.7 & 0.5 \\
$2010 / 2011$ & 35.0 & 12.0 & 15.1 & 24.9 & 0.9 & 1.1 & 2.8 & 8.8 & -0.6 \\
$2011 / 2012$ & 34.9 & 20.1 & 18.6 & 20.4 & 0.3 & 2.4 & 22.6 & 9.8 & -29.0 \\
$2012 / 2013$ & 21.3 & 9.2 & 11.2 & 12.3 & 3.6 & -3.2 & 13.6 & 3.9 & 28.1 \\
$2013 / 2014$ & 27.2 & 9.3 & 13.8 & 15.2 & 1.7 & 5.0 & 16.4 & 5.5 & 5.9 \\
$2014 / 2015$ & 14.1 & 7.6 & 14.9 & 13.9 & 1.5 & 3.8 & 4.6 & 0.8 & 38.9 \\
$2015 / 2016$ & 48.5 & 16.9 & 30.7 & -13.1 & 3.4 & 1.4 & 9.6 & -1.2 & 3.8 \\
Average (\%) & 29.8 & 13.1 & 11.3 & 11.9 & 1.4 & 1.7 & 7.4 & 5.1 & 18.3 \\
\hline
\end{tabular}

Source: Authors' computations (see also Bachewe et al. 2018).

Note: Decomposition uses factor shares in 2009/2010 Ethiopia SAM (EDRI 2009). Real values of crop output reported.

\section{References}

Abate, G. T., T. Bernard, S. Makhija, and D. J. Spielman. 2019. Accelerating Technical Change Through Video-Mediated Agricultural Extension: Evidence from Ethiopia. IFPRI Discussion Paper 1851 (June). Washington, DC: International Food Policy Research Institute (IFPRI).

Abate, T., B. Shiferaw, A. Menkir, D. Wegary, Y. Kebede, K. Tesfaye, M. Kassie, G. Bogale, B.

Tadesse, and T. Keno. 2015. "Factors That Transformed Maize Productivity in Ethiopia." Food Security 7 (5): 965-981.

Abay, K. A., G. Berhane, A. S. Taffesse, K. Abay, and B. Koru. 2018. "Estimating Input Complementarities with Unobserved Heterogeneity: Evidence from Ethiopia." Journal of Agricultural Economics 69 (2): 495-517.

African Union. 2010. Comprehensive Africa Agriculture Development Programme (CAADP). Addis Ababa.

Agbahey, J. U., H. Grethe, and W. Negatu. 2015. "Fertilizer Supply Chain in Ethiopia: Structure, Performance and Policy Analysis." Afrika Focus 28 (1): 81-101.

AGRA (Alliance for a Green Revolution in Africa). 2018. Africa Agriculture Status Report: Catalyzing Government Capacity to Drive Agricultural Transformation (Issue 6). Nairobi, Kenya. 
Alem, Y., M. Bezabih, M. Kassie, and P. Zikhali. 2010. "Does Fertilizer Use Respond to Rainfall Variability? Panel Data Evidence from Ethiopia." Agricultural Economics 41 (2): 165-175.

Alemu, D., D. Byerlee, D. Spielman, and M. Gautam. 2007. Policies to Promote Cereal Intensification in Ethiopia: A Review of Evidence and Experience. IFPRI Discussion Paper 707. Washington, DC: IFPRI.

Alemu, D., S. Rashid, and R. Tripp. 2019. “Seed System Potential in Ethiopia: Constraints and Opportunities for Enhancing the Seed Sector." Gates Open Research 3. Accessed March 9, 2020. https://gatesopenresearch.org/documents/3-948.

Ali, D. A., and K. Deininger. 2014. "Causes and Implications of Credit Rationing in Rural Ethiopia: The Importance of Zonal Variation.” Journal of African Economies 23 (4): 493-527.

Ali, D., K. Deininger, and A. Harris. 2019. "Does Large Farm Establishment Create Benefits for Neighboring Smallholders? Evidence from Ethiopia." Land Economics 95 (1): 71-90.

ASTI (Agricultural Science and Technology Indicators). 2019. ASTI database. Accessed June 21, 2019. https://www.asti.cgiar.org/data.

ATA (Agricultural Transformation Agency of Ethiopia). 2010. 2010/11 Annual Report. Addis Ababa, Ethiopia.

— . 2017a. "Seed System Development Strategy: Vision, Systemic Challenges, and Prioritized Interventions." Working Strategy Document, Addis Ababa.

— 2017b. 2016/17 Annual Report. Addis Ababa.

_ . 2019. "EthioSIS." Accessed October 15, 2019. www.ata.gov.et/programs/highlighted -deliverables/ethiosis/.

Awulachew, S. B., A. D. Yilma, M. Loulseged, W. Loiskandl, M. Ayana, and T. Alamirew. 2007. "Water Resources and Irrigation Development in Ethiopia." Colombo, Sri Lanka: International Water Management Institute (IWMI). IWMI Working Paper 123. http://dx .doi.org/10.3910/2009.305.

Bachewe, F. N., G. Berhane, B. Minten, and A. S. Taffesse. 2018. "Agricultural Transformation in Africa? Assessing the Evidence in Ethiopia." World Development 105: 286-298.

Beintema, N., and T. Hargewoin. 2018. Ethiopia, Agricultural R\&D Indicators Factsheet Update August 2018. Washington, DC: Agricultural Science and Technology Indicators (ASTI), program of IFPRI.

Benin, S., and A. Nin-Pratt. 2016. "Intertemporal Trends in Agricultural Productivity." In Agricultural Productivity in Africa: Trends, Patterns, and Determinants, edited by S. Benin, 25-104. Washington, DC: IFPRI. 
Berhane, G., and K. A. Abay. 2019. "Rural Finance and Smallholder Farming in Ethiopia." In The Oxford Handbook of the Ethiopian Economy, edited by F. Cheru, C. Cramer, and A. Oqubay, 487-504. Oxford, UK: Oxford University Press.

Berhane, G., and T. Assefa. 2020. "Fertilizer Profitability in Ethiopia." ESSP Working Paper. Addis Ababa: IFPRI, forthcoming.

Berhane, G., F. Bachewe, and B. Minten. 2018. "Agricultural Transformation in Ethiopia: What Do We Know?” In Africa Agriculture Status Report 2018: Catalyzing Government Capacity to Drive Agricultural Transformation. Nairobi, Kenya: Alliance for a Green Revolution in Africa (AGRA).

Berhane, G., M. Dereje, B. Minten, and S. Tamru. 2017. The Rapid - But from a Low BaseUptake of Agricultural Mechanization in Ethiopia: Patterns, Implications and Challenges. IFPRI-ESSP Working Paper 105. Addis Ababa: IFPRI/Ethiopia Strategy Support Program (ESSP).

Berhane, G., and C. Gardebroek. 2011. "Does Microfinance Reduce Rural Poverty? Evidence Based on Household Panel Data from Northern Ethiopia." American Journal of Agricultural Economics 93 (1): 43-55.

Berhane, G., C. Ragasa, G. Abate, and T. W. Assefa. 2018. The State of Agricultural Extension Services in Ethiopia and Their Contribution to Agricultural Productivity. IFPRI-ESSP Working Paper 118. Addis Ababa: IFPRI/ESSP.

Bezawagaw, M. G., N. C. Dihel, M. T. Geiger, and G. K. Zerihun. 2018. Ethiopia Economic Update: The Inescapable Manufacturing Services Nexus: Exploring the Potential of Distribution Services. Washington, DC: World Bank.

Bezu, S., and S. Holden. 2014. “Are Rural Youth in Ethiopia Abandoning Agriculture?” World Development 64: 259-272.

Binswanger, H. P., and M. R. Rosenzweig. 1986. "Behavioural and Material Determinants of Production Relations in Agriculture.” Journal of Development Studies 22 (3): 503-539.

Croppenstedt, A., M. Demeke, and M. M. Meschi. 2003. “Technology Adoption in the Presence of Constraints: The Case of Fertilizer Demand in Ethiopia." Review of Development Economics 7 (1): 58-70.

Davis, K., B. Swanson, D. Amudavi, D. A. Mekonnen, A. Flohrs, J. Riese, C. Lamb, and E. Zerfu. 2010. In-depth Assessment of the Public Agricultural Extension System of Ethiopia and Recommendations for Improvement. IFPRI Discussion Paper 1041. Washington, DC: IFPRI.

Deininger, K., D. Ayalew, and T. Alemu. 2011. "Impacts of Land Certification on Tenure Security, Investment, and Land Market Participation: Evidence from Ethiopia." Land Economics 87 (2): 312-334. 
Deininger, K., D. Ayalew, S. Holden, and J. Zevenbergen. 2008. “Rural Land Certification in Ethiopia: Process, Initial Impact, and Implications for Other African Countries." World Development 36 (10): 1786-1812.

Deneke, T. T., and D. Gulti. 2016. "Agricultural Research and Extension Linkages in the Amhara Region, Ethiopia." In Technological and Institutional Innovations for Marginalized Smallholders in Agricultural Development, edited by F. Gatzweiler and J. von Braun, 113124. Switzerland: Springer International Publishing.

EDRI (Ethiopian Development Research Institute). 2009. Ethiopia: Input Output Table and Social Accounting Matrix. Addis Ababa: EDRI.

Ethiopia, CSA (Central Statistical Agency). 2005-2020. Agricultural Sample Survey: Report on Farm Management Practices (Private Peasant Holdings, Meher Season). Volume 3. Addis Ababa. Ethiopia, MoFED (Ministry of Finance and Economic Development). 2006. Ethiopia: Building on Progress - A Plan for Accelerated and Sustained Development to End Poverty (PASDEP) (2005/06-2009/10). Volume 1, Main Text. Addis Ababa.

- 2010. Growth and Transformation Plan II (GTP II) (2010/11-2014/15). Volume 1, Main Text. Addis Ababa.

Ethiopia, NPC (National Planning Commission). 2018. The Second Growth and Transformation Plan (GTP II) Midterm Review Report. Addis Ababa.

Evenson, R. E., and J. W. McKinsey. 1999. Technology - Climate Interactions in the Green Revolution in India. Center Discussion Paper 805. Addis Ababa.

Fuglie, K. O. 2004. "Productivity Growth in Indonesian Agriculture, 1961-2000.” Bulletin of Indonesian Economic Studies 40 (2): 209-225.

- 2008. "Is a Slowdown in Agricultural Productivity Growth Contributing to the Rise in Commodity Prices?” Agricultural Economics 39 (s1): 431-441.

Fuglie, K., and N. Rada. 2013. Resources, Policies, and Agricultural Productivity in Sub-Saharan Africa. Economic Research Service Report 145. Washington, DC: United States Department of Agriculture.

Gebrehiwot, B. D., and S. T. Holden. 2019. "Variation in Output Shares and Endogenous Matching in Land Rental Contracts: Evidence from Ethiopia." Journal of Agricultural Economics 71 (1): 260-282.

Gebru, M., S. T. Holden, and M. Tilahun. 2019. “Tenants' Land Access in the Rental Market: Evidence from Northern Ethiopia." Agricultural Economics 50 (3): 291-302.

Ghebru, H. H. 2010. "Land Policy Reform and Land Rental Markets in Ethiopia: Equity, Productivity and Welfare Implications." PhD dissertation, Norwegian University of Life Sciences, Ås. 
Ghebru, H., and S. Holden. 2013. Links between Tenure Security and Food Security: Evidence from Ethiopia. IFPRI-ESSP Working Paper 59. Addis Ababa: IFPRI/EDRI.

Ghebru, H., B. Koru, and A. S. Taffesse. 2016. Household Perception and Demand for Better Protection of Land Rights in Ethiopia. IFPRI-ESSP Working Paper 83. Washington, DC: IFPRI; Addis Ababa: EDRI.

Haddis, Z. 2013. “Towards Improved Transactions of Land Use Rights in Ethiopia.” Paper prepared for presentation at the Annual World Bank Conference on Land and Poverty, World Bank, Washington, DC, April 8-11.

Hazell, P. B. 2009. The Asian Green Revolution. Vol. 911. Washington, DC: IFPRI. 2013. "Options for African Agriculture in an Era of High Food and Energy Prices.” Agricultural Economics 44 (s1): 19-27.

Headey, D., M. Dereje, and A. S. Taffesse. 2014. "Land Constraints and Agricultural Intensification in Ethiopia: A Village-Level Analysis of High-Potential Areas." Food Policy 48: 129-141.

Hill, R. V., and E. Tsehaye. 2018. Growth, Safety Nets and Poverty: Assessing Progress in Ethiopia from 1996 to 2011 (English). Policy Research working paper series 8380. Washington, DC: World Bank.

Holden, S., K. Deininger, and H. Ghebru. 2007. "Impacts of Low-Cost Land Certification on Investment and Productivity." American Journal of Agricultural Economics 91 (2):359-373.

Holden, S. T., and H. Ghebru. 2016. "Land Rental Market Legal Restrictions in Northern Ethiopia." Land Use Policy 55: 212-221.

Holden, S., K. Otsuka, and K. Deininger, eds. 2013. Land Tenure Reform in Asia and Africa: Assessing Impacts on Poverty and Natural Resource Management. London: Palgrave Macmillan.

Hopper, W. 1993. "Indian Agriculture and Fertilizer: An Outsider's Observations." Keynote address given at the Fertiliser Association of India (FAI) Seminar on Emerging Scenarios in Fertilizer and Agriculture: Global Dimensions. New Delhi, India.

IFDC (International Fertilizer Development Center). 2015. Assessment of Fertilizer Consumption and Use by Crop in Ethiopia. Report. Muscle Shoals, AL, US.

Jayne, T. S., J. Chamberlin, and R. Benfica. 2018. “Africa’s Unfolding Economic Transformation.” Journal of Development Studies 54 (5): 777-787.

Kassa, T. A., T. Luck, A. Bekele, and S. G. Riedel-Heller. 2016. "Sexual and Reproductive Health of Young People with Disability in Ethiopia: A Study on Knowledge, Attitude and Practice: A Cross-sectional Study." Globalization and Health 12 (1): 5. 
Kiran, C., S. Siddiqui, J. Barron, C. Subsasinghe, and A. Haileselassie. 2018. Ecological Footprint of Food Security: Mapping Irrigated Area in Ethiopia. Unpublished, IWMI.

Krishnan, P., and M. Patnam. 2014. "Neighbors and Extension Agents in Ethiopia: Who Matters More for Technology Adoption?” American Journal of Agricultural Economics 96 (1): $308-327$.

Laborde, D., T. Lallemant, K. McDougal, C. Smaller, and F. Traore. 2018. Transforming Agriculture in Africa and Asia: What Are the Policy Priorities? Winnipeg, Canada: International Institute for Sustainable Development (IISD).

Makhija, S., D. J. Spielman, G. T. Abate, and T. Bernard. 2019. "Opportunities and Challenges in Field Data Validation and Corroboration: Matching Household Survey Data with Project Monitoring Data in Ethiopia." IFPRI Project Note (May). Washington, DC: IFPRI. http:// ebrary.ifpri.org/cdm/singleitem/collection/p15738coll2/id/133257/rec/3.

Melesse, M. B., and E. Bulte. 2015. "Does Land Registration and Certification Boost Farm Productivity? Evidence from Ethiopia.” Agricultural Economics 46 (6): 757-768.

Mellor, J. W. 2014. “Rapid Cereals Production Growth, 1997-2012, Ethiopia.” Accessed March 19, 2020. https://www.johnwmellor.com/s/AERgrowthratesethiopiamellor-z5h3.docx.

Minten, B., A. S. Taffesse, and P. Brown, eds. 2018. The Economics of Teff: Exploring Ethiopia's Biggest Cash Crop. Washington, DC: IFPRI.

Minten, B., S. Tamru, E. Engida, and T. Kuma. 2013. Ethiopia's Value Chains on the Move: The Case of Teff. IFPRI-ESSP Working Paper 52. Addis Ababa: IFPRI/Ethiopia Strategy Support Program II (ESSP II).

Nin-Pratt, A. 2016. "Inputs, Productivity and Agricultural Growth in Sub-Saharan Africa." In Productivity and Efficiency Analysis, edited by W. Greene, L. Khalaf, R. Sickles, M. Veall, and M. C. Voia. Cham, Switzerland: Springer. DOI: https://doi.org/10.1007/ 978-3-319-23228-7_11.

Rashid, S., N. Tefera, N. Minot, and G. Ayele. 2013. "Can modern input use be promoted without subsidies? An analysis of fertilizer in Ethiopia.” Agricultural Economics 44 (6): 595-611. Special Issue on Input Subsidy Programs (ISPs) in Sub-Saharan Africa (SSA). http://online library.wiley.com/doi/10.1111/agec.12076/abstract.

Ricker-Gilbert, J., T. S. Jayne, and E. Chirwa. 2011. "Subsidies and Crowding Out: A Double-hurdle Model of Fertilizer Demand in Malawi." American Journal of Agricultural Economics 93 (1): 26-42.

Rosegrant, M. W., and P. B. Hazell. 2000. Transforming the Rural Asian Economy: The Unfinished Revolution. Hong Kong: Oxford University Press.

Ruttan, V. W. 2002. "Productivity Growth in World Agriculture: Sources and Constraints." Journal of Economic Perspectives 16 (4): 161-184. 
Sheahan, M., and C. B. Barrett. 2014. Understanding the Agricultural Input Landscape in SubSaharan Africa: Recent Plot, Household, and Community-Level Evidence. Policy Research Working Paper Series 7014. Africa Region Office of the Chief Economist, World Bank.

_. 2017. "Ten Striking Facts about Agricultural Input Use in Sub-Saharan Africa." Food Policy 67: 12-25.

Sheng, Y., E. Ball, and K. Nossal. 2015. "Comparing Agricultural Total Factor Productivity between Australia, Canada, and the United States, 1961-2006." International Productivity Monitor 29: 38-59.

Solow, R. M. 1957. "Technical Change and the Aggregate Production Function." Review of Economics and Statistics 39 (3): 312-320.

Spielman, D. J., D. Byerlee, D. Alemu, and D. Kelemework. 2010. "Policies to Promote Cereal Intensification in Ethiopia: The Search for Appropriate Public and Private Roles." Food Policy 35 (3): 185-194.

Spielman, D. J., D. Kelemework, and D. Alemu. 2012. “Seed, Fertilizer, and Agricultural Extension in Ethiopia." In Food and Agriculture in Ethiopia: Progress and Policy Challenges, edited by P. A. Dorosh and S. Rashid, 84-122. Philadelphia: University of Pennsylvania Press.

Sumner, D. A. 2014. “American Farms Keep Growing: Size, Productivity and Policy.” Journal of Economic Perspectives 28 (1): 147-166.

Tomich, T., P. Kilby, and B. Johnson. 1995. Transforming Agrarian Economies: Opportunities Seized, Opportunities Missed. Ithaca, NY, US: Cornell University Press.

USAID. 2013. “Agricultural Growth Program-Livestock Market Development. End Market Analysis for Meat/Live Animals, Leather and Leather Products, Dairy Products Value Chains." Expanding Livestock Markets for the Small-Holder Producers. Prepared by AGP-Livestock Market Development Project.

Vandercasteelen, J., M. Dereje, B. Minten, and A. S. Taffesse. 2013. Scaling-Up Adoption of Improved Technologies: The Impact of the Promotion of Row Planting on Farmers' Teff Yields in Ethiopia. LICOS Discussion Paper 344. Leuven, Belgium: Katholieke Universiteit Leuven, LICOS Centre for Institutions and Economic Performance.

World Bank. 2016. Ethiopia Public Expenditure Review. Report ACS14541. Washington, DC: World Bank.

Yirga, C., K. Negisho, L. Oruko, D. Alemu, and G. Taxler. 2016. Tracking the Diffusion of Crop Varieties Using DNA Fingerprinting. Addis Ababa: Ethiopian Institute of Agricultural Research (EIAR).

Zelleke, G., G. Agegnehu, D. Abera, and S. Rashid. 2010. Fertilizer and Soil Fertility Potential in Ethiopia - Constraints and Opportunities for Enhancing the System. Working Paper July 2010. Washington, DC: IFRI. 
